A coreografia Fogo Negro, foi inspirada na Novela Venus im Pelz, do autor austríaco Leopold von Sacher-Masoch, publicada em 1870. A qual por sua vez inspirou a criação da música utilizada na dança: Venus in Furs, lançada em 1960 no álbum The Velvet Underground \& Nico, produzido por Andy Warhol como rock experimental. Na coreografia, Soraia Silva busca criar uma integração das imagens poéticas da música com um poemadança por ela criado sobre os mistérios da sedução da arte da dança.

As imagens do trabalho foram realizadas durante a performance apresentada na VIII Mostra de Dança do SESC Presidente Dutra em Brasília nos dias 10 e 11 de dezembro de 2016. Poema, Coreografia, performance e figurino Soraia Maria Silva. Edição da trilha sonora Glauco Maciel. Iluminação: Edson Pedro, Gilberto Cançado e Luís Montalván. Fotos: Clara Cavalcante \& Andrea Tibery.

\title{
poemadançando fogo negro
}

Os teus acenos articulam

Amarras! Subjugas! Livremente modelas...

Em desejos submetes! Nunca te sacias... Ardes ardis.

\section{Uma costela de mim...retiras o que dás!}

Joelhos hesitam, excitam...

Param os meus pés! Doentes de alturas: sangram. No auge dos seus transes quebraste-me. Às suas ordens incólume o meu corpo se adere.

\section{Conforma-se.}


Os meus quadris doem ao que aprendi de ti!

\section{O fiel imóvel, imponderável:}

Desloca!!!!! Ai.

Bases incandescentes traspassadas em calos de $t_{\text {empoe }}$ paço

Interminável palma, Esquerda flor

na mão do agora: dançam invisíveis edifícios! 


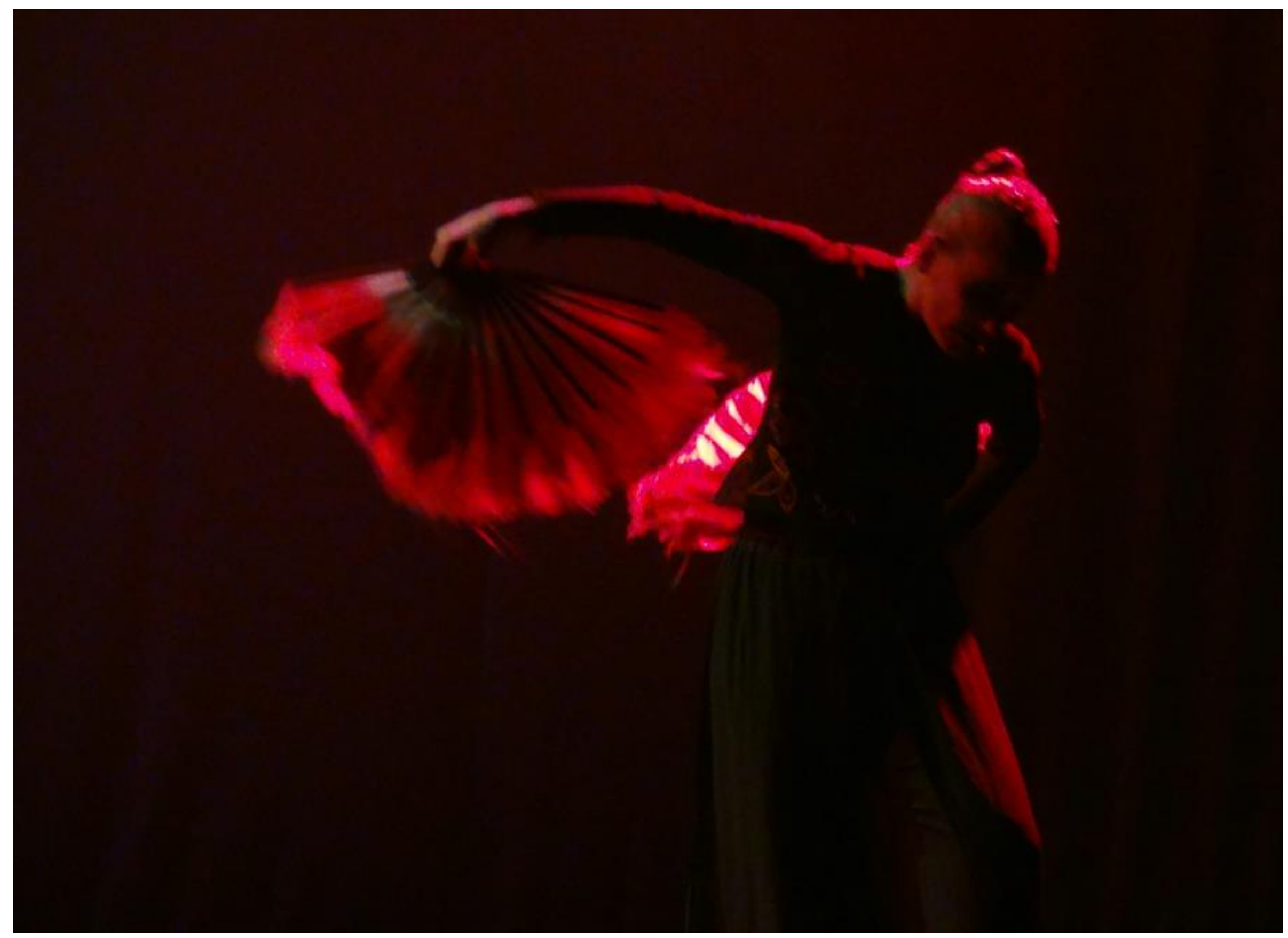




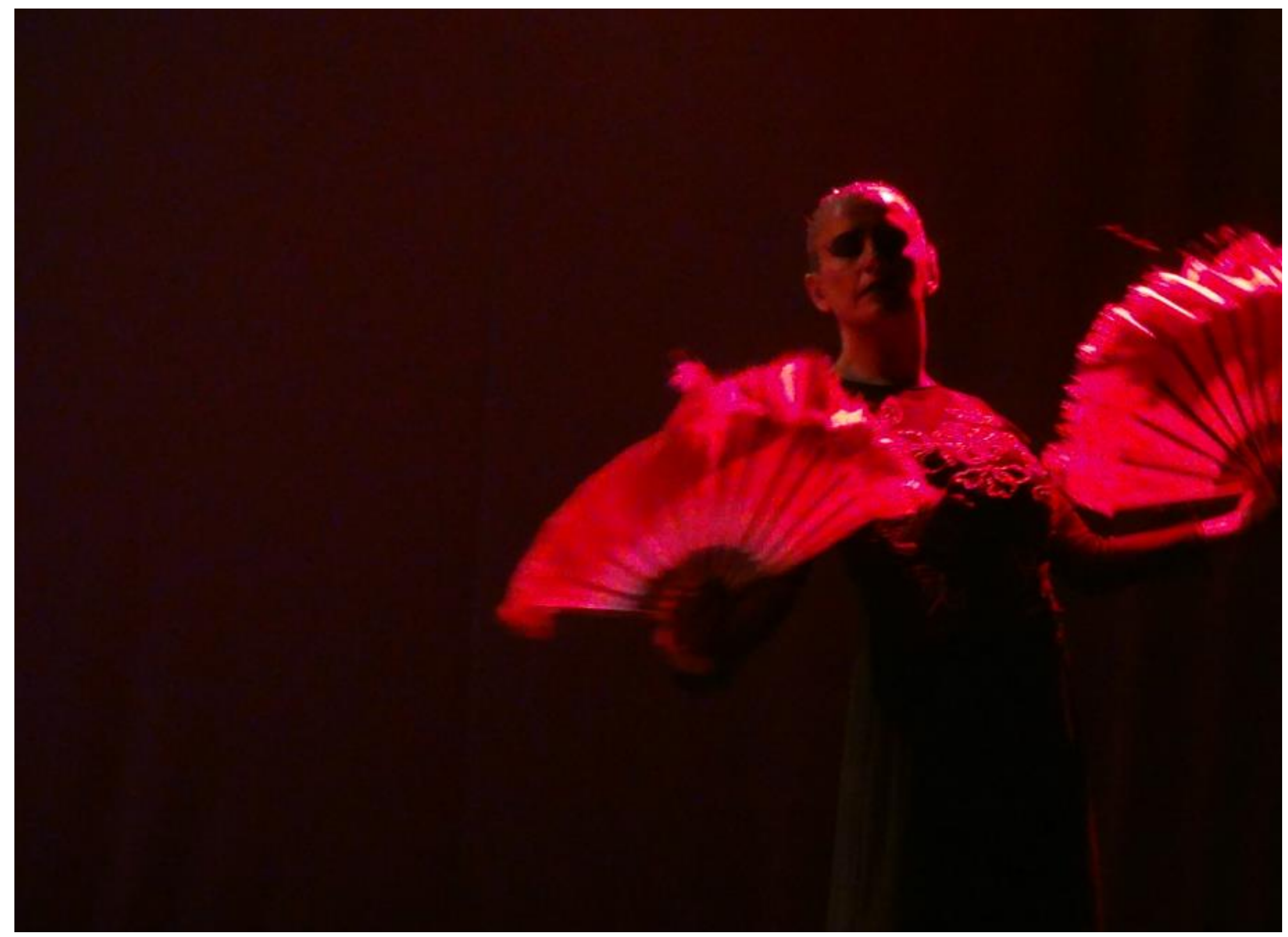




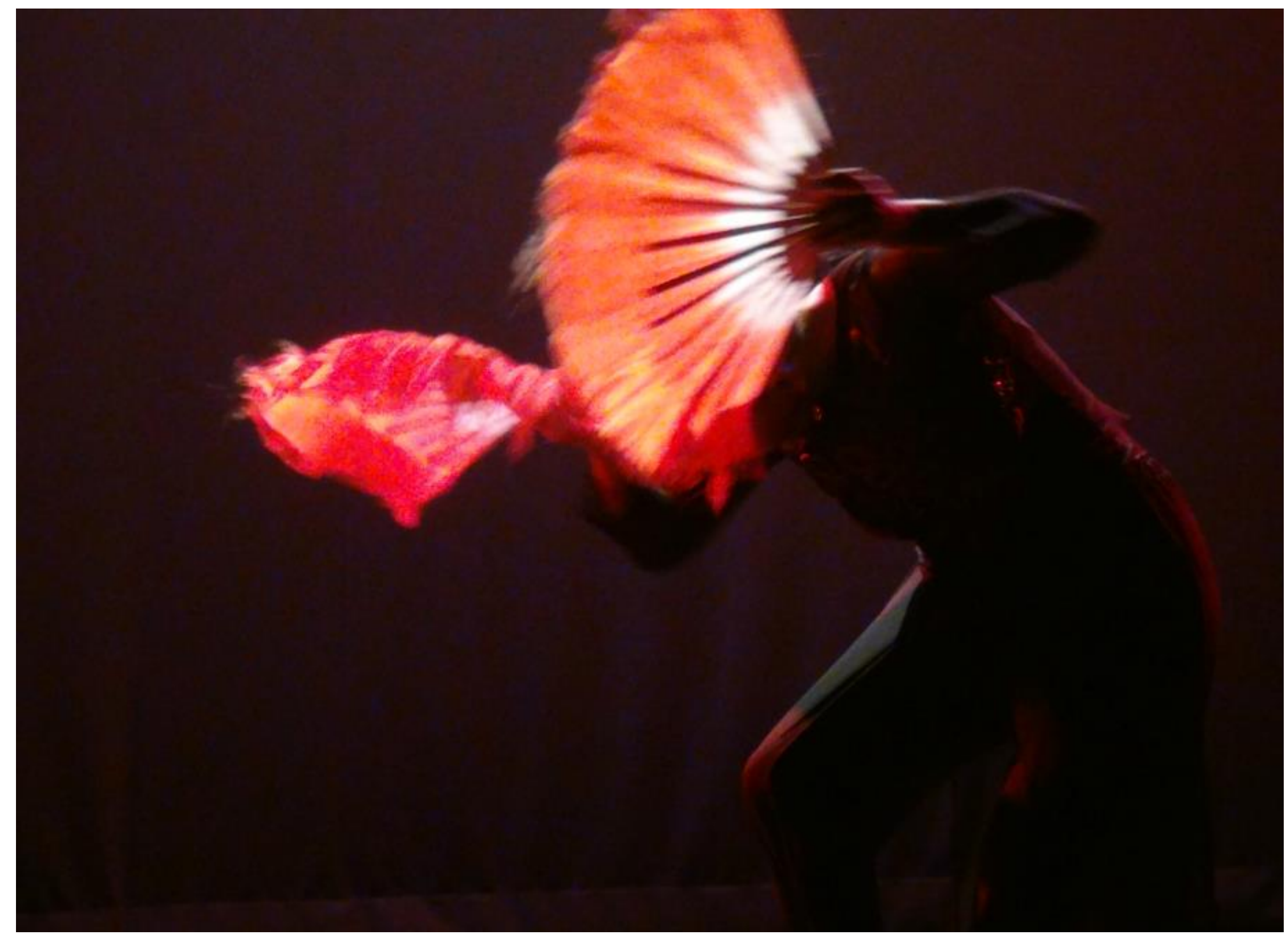




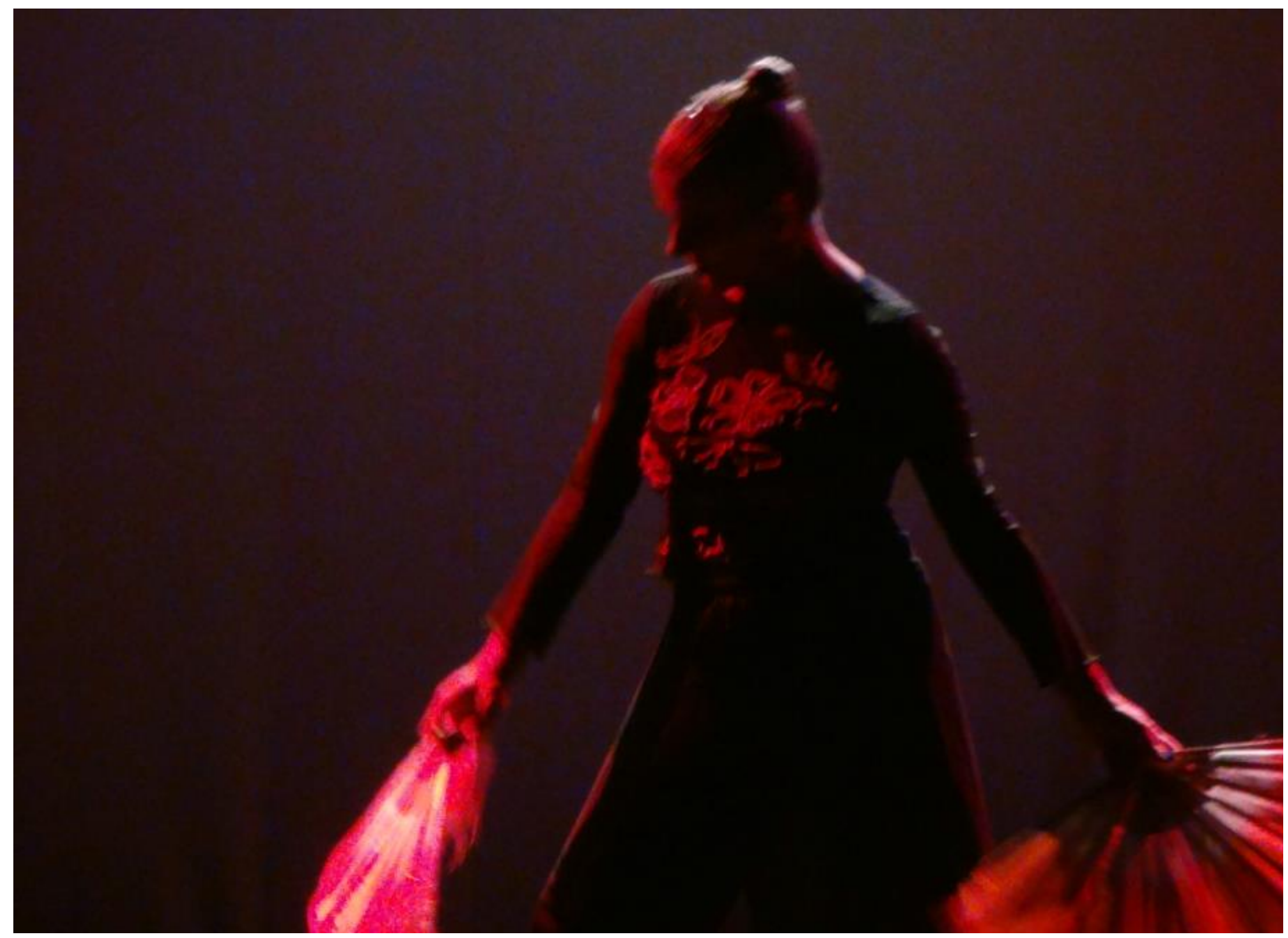




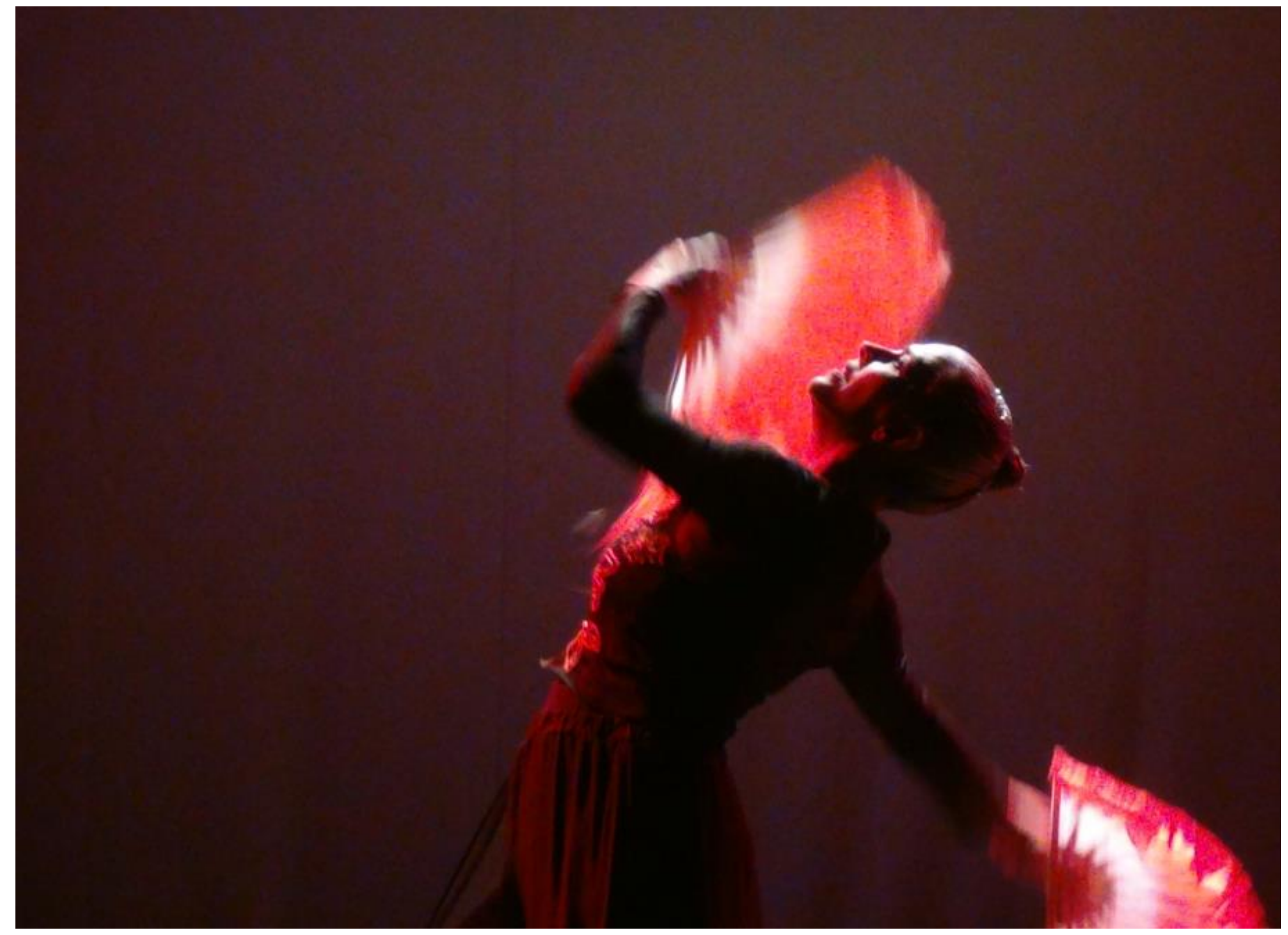


METAgraphias: letra D de Dropbox (das derivas dançantes) v.2 n.1 marçol2017 poemadançando fogo negro•Soraia Silva (soraia@unb.br)

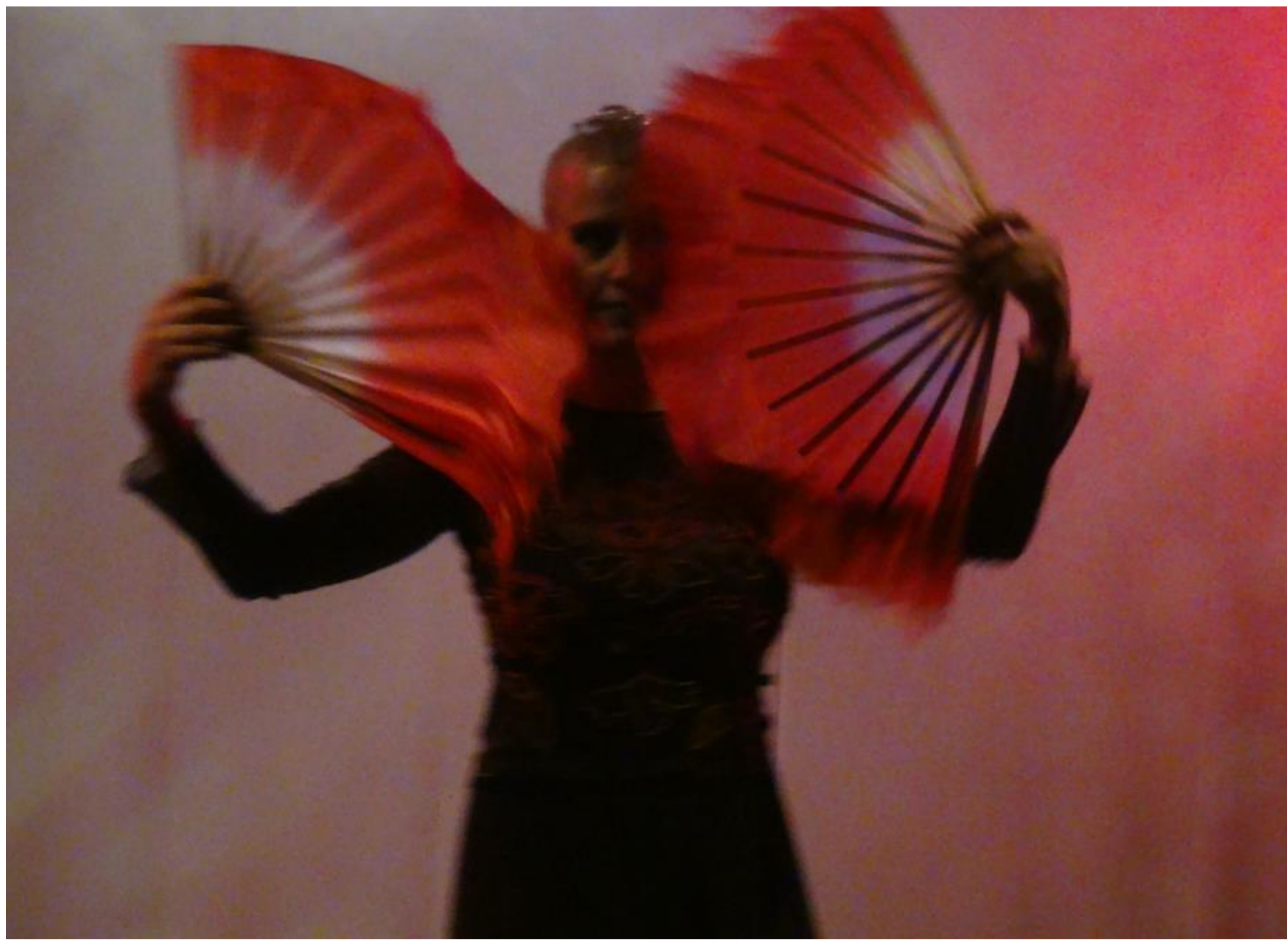




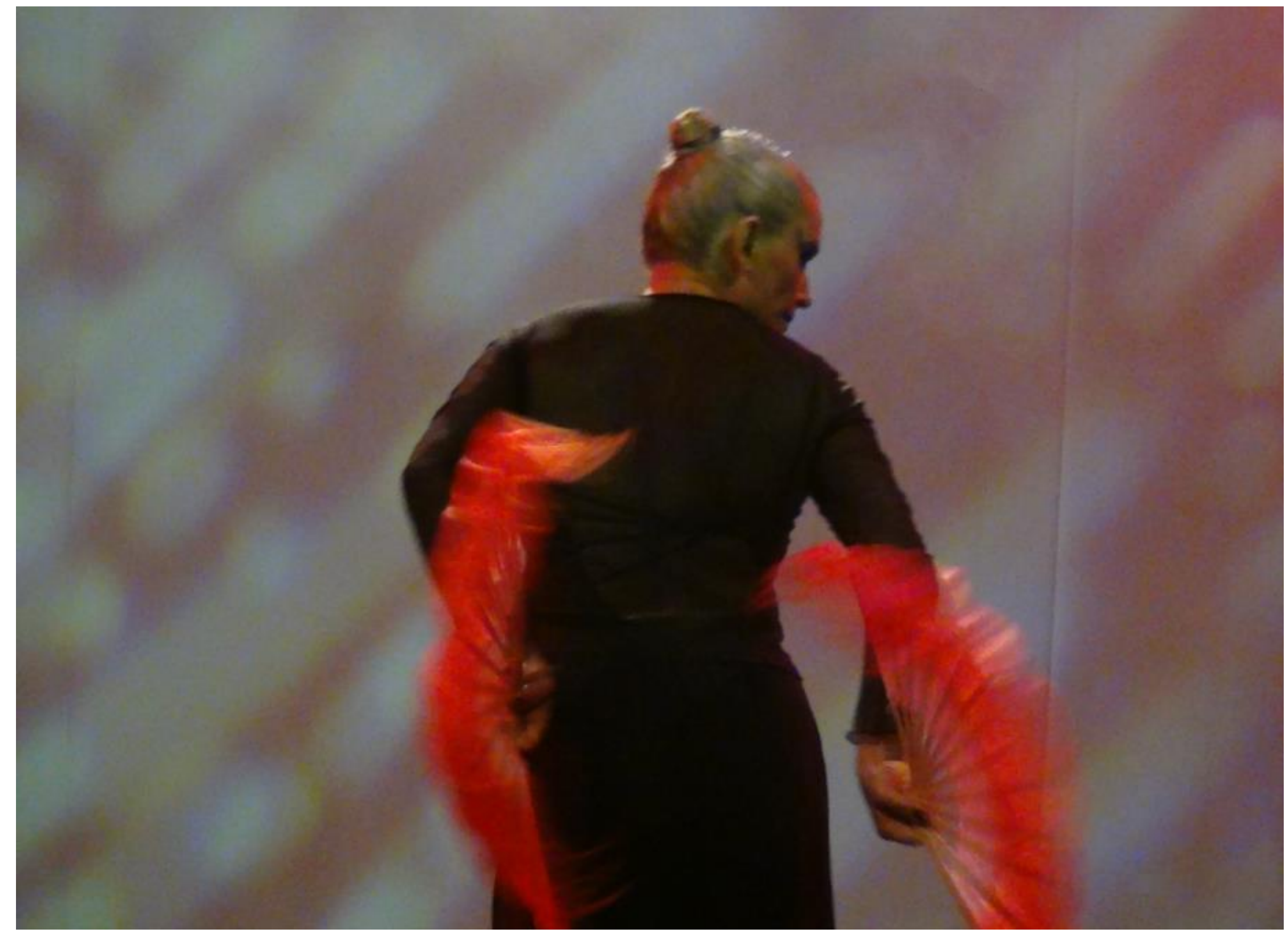


METAgraphias: letra D de Dropbox (das derivas dançantes) v.2 n.1 marçol2017 poemadançando fogo negro•Soraia Silva (soraia@unb.br)

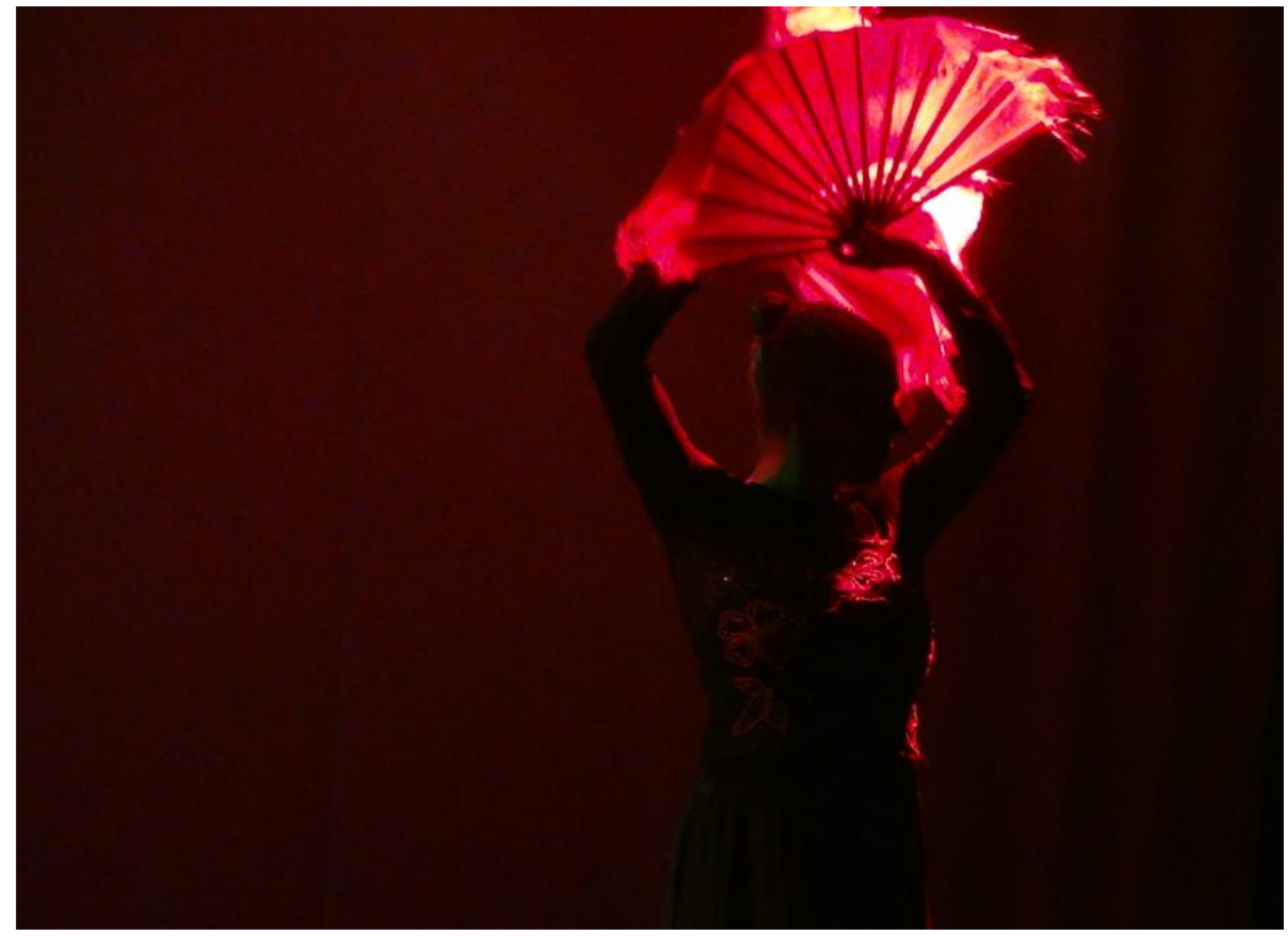




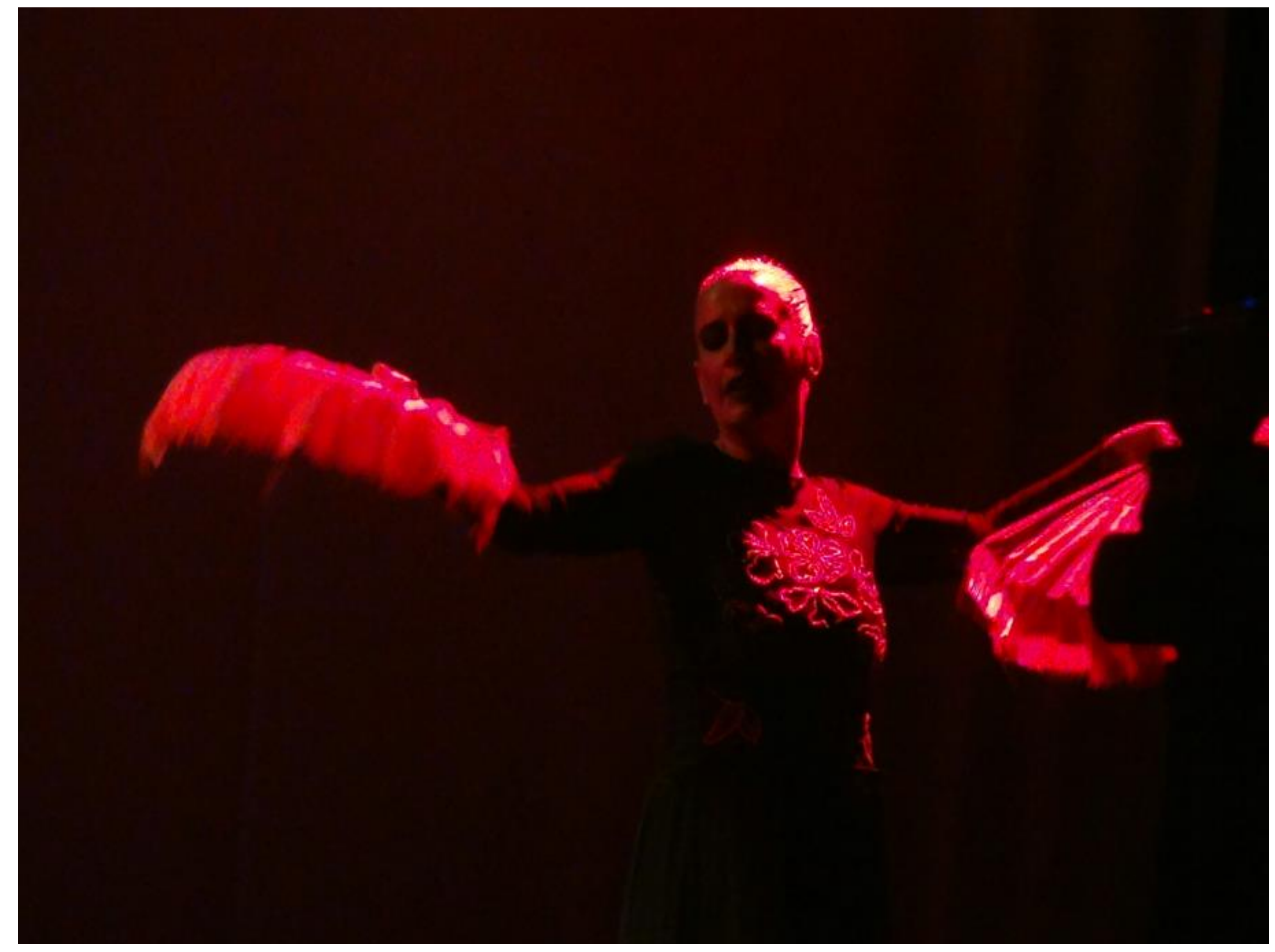


METAgraphias: letra D de Dropbox (das derivas dançantes) v.2 n.1 marçol2017 poemadançando fogo negro•Soraia Silva (soraia@unb.br)
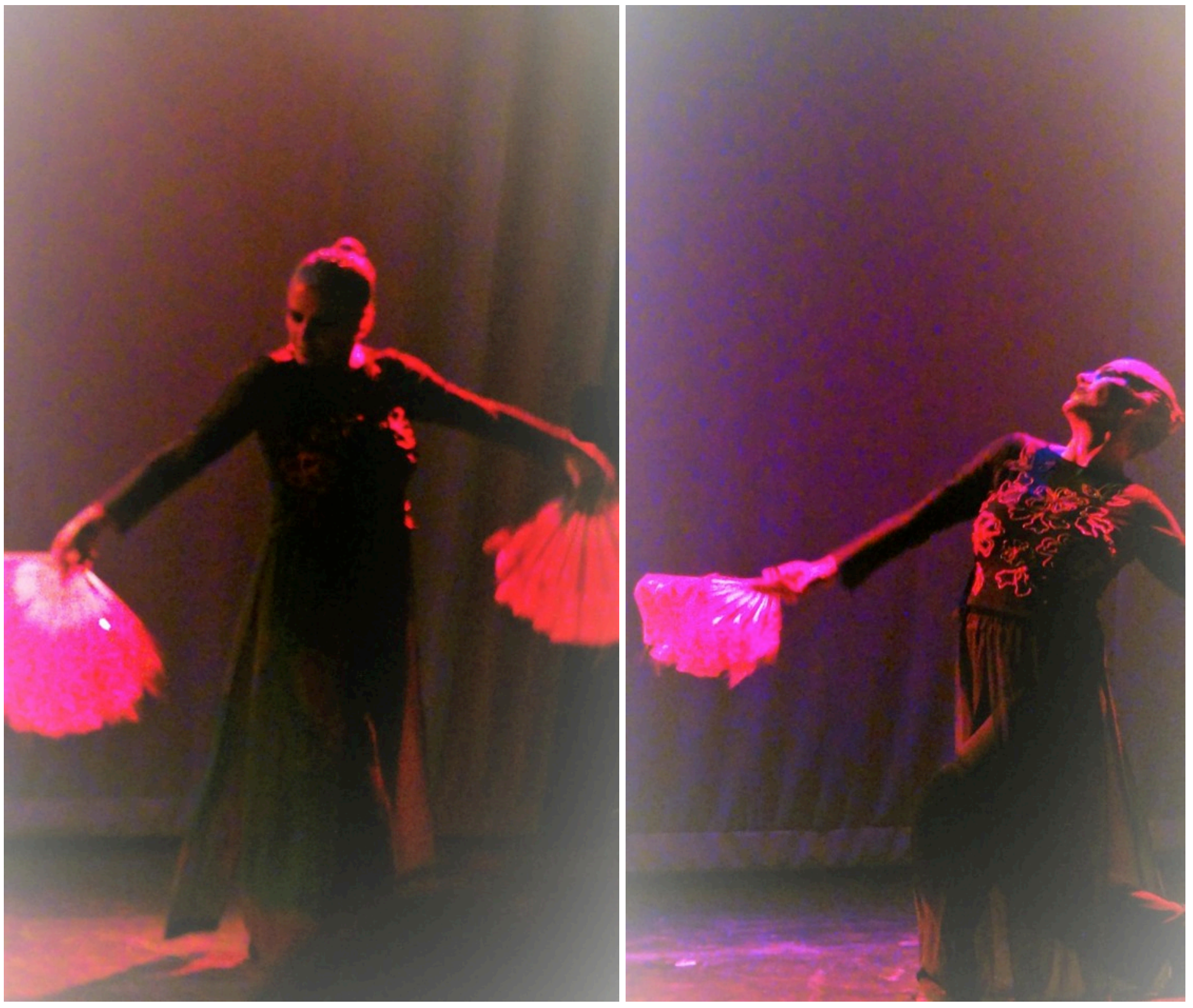
METAgraphias: letra D de Dropbox (das derivas dançantes) v.2 n.1 marçol2017 poemadançando fogo negro•Soraia Silva (soraia@unb.br)

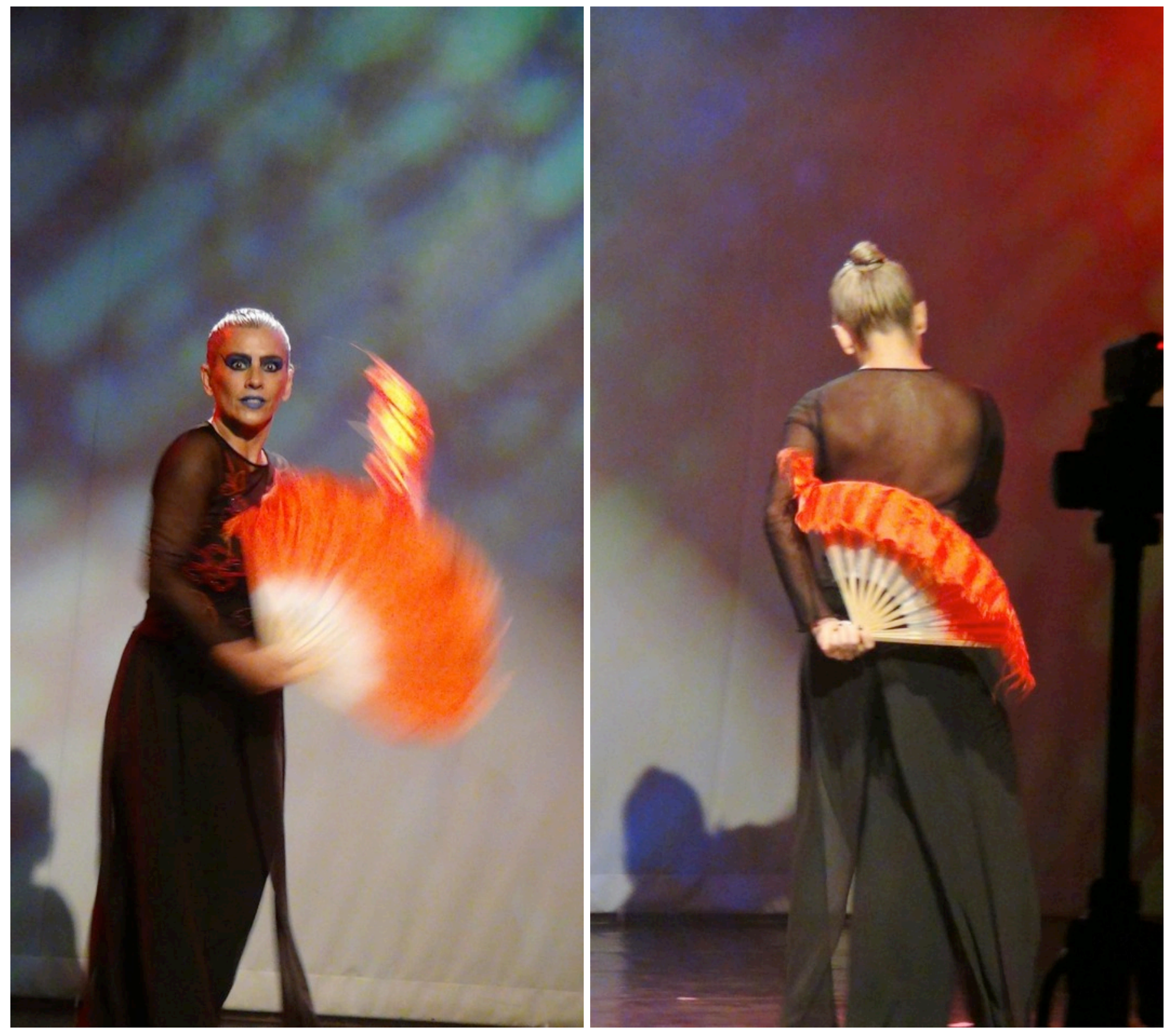


METAgraphias: letra D de Dropbox (das derivas dançantes) v.2 n.1 marçol2017 poemadançando fogo negro•Soraia Silva (soraia@unb.br)
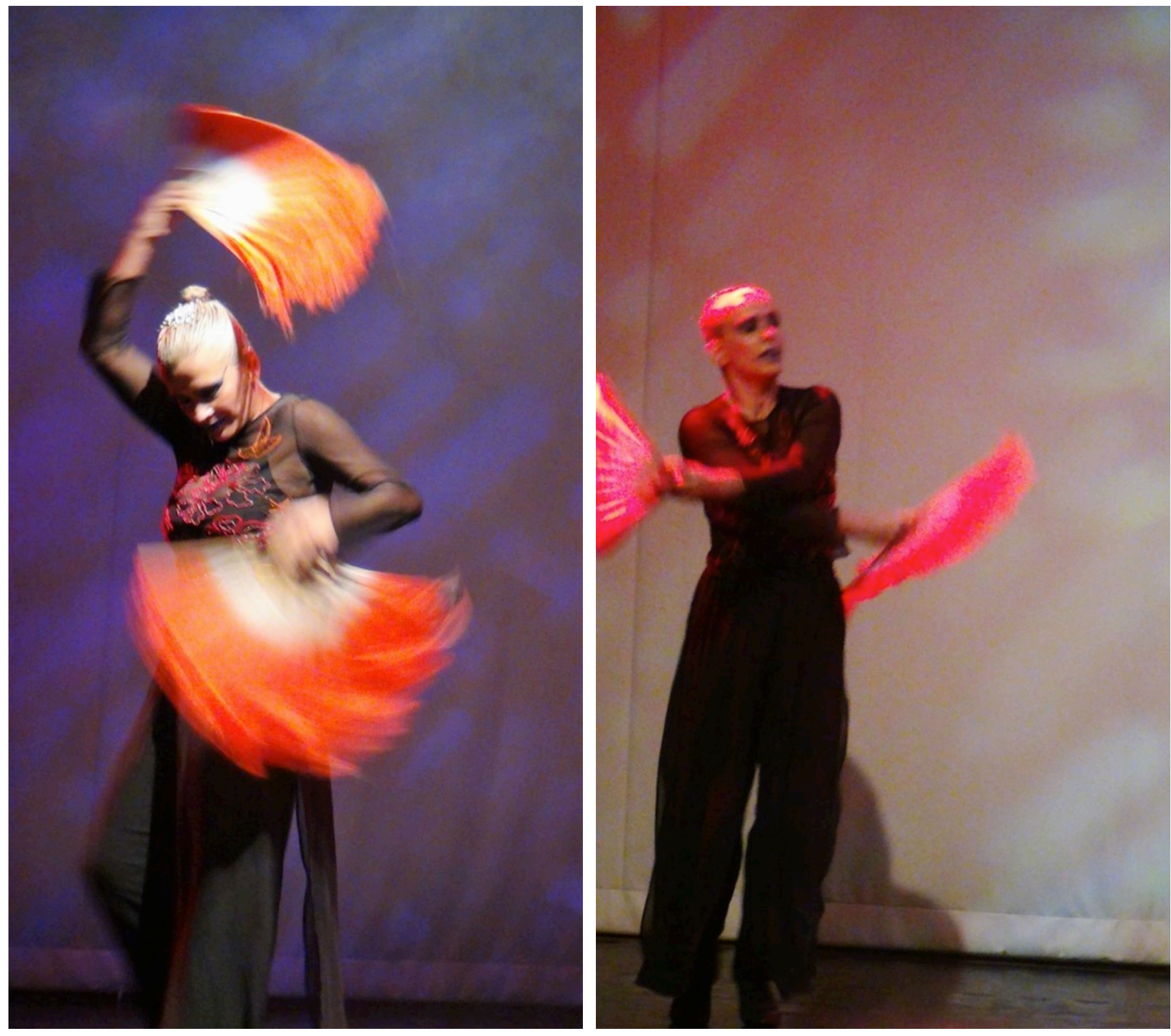
METAgraphias: letra D de Dropbox (das derivas dançantes) v.2 n.1 marçol2017 poemadançando fogo negro•Soraia Silva (soraia@unb.br)

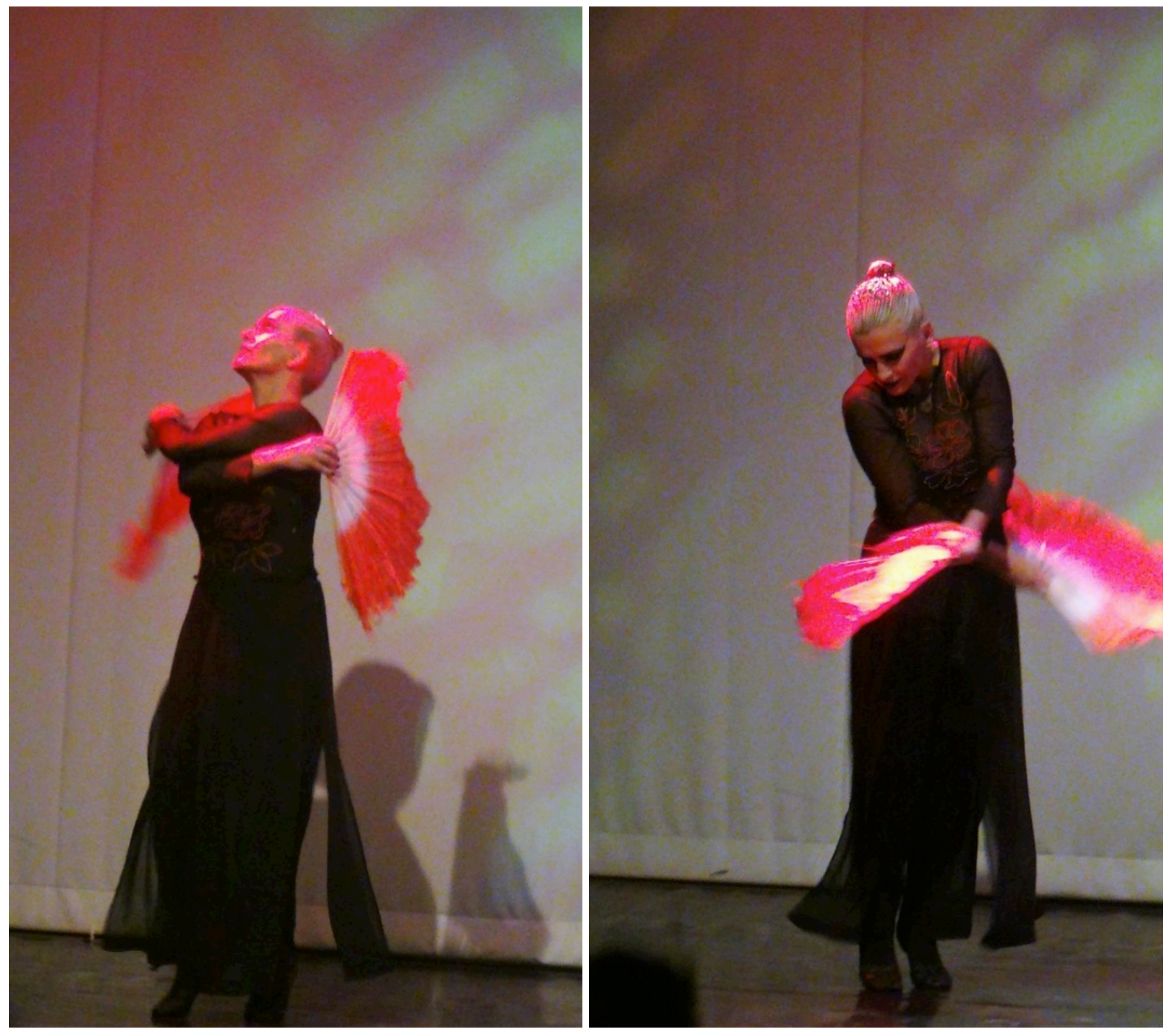




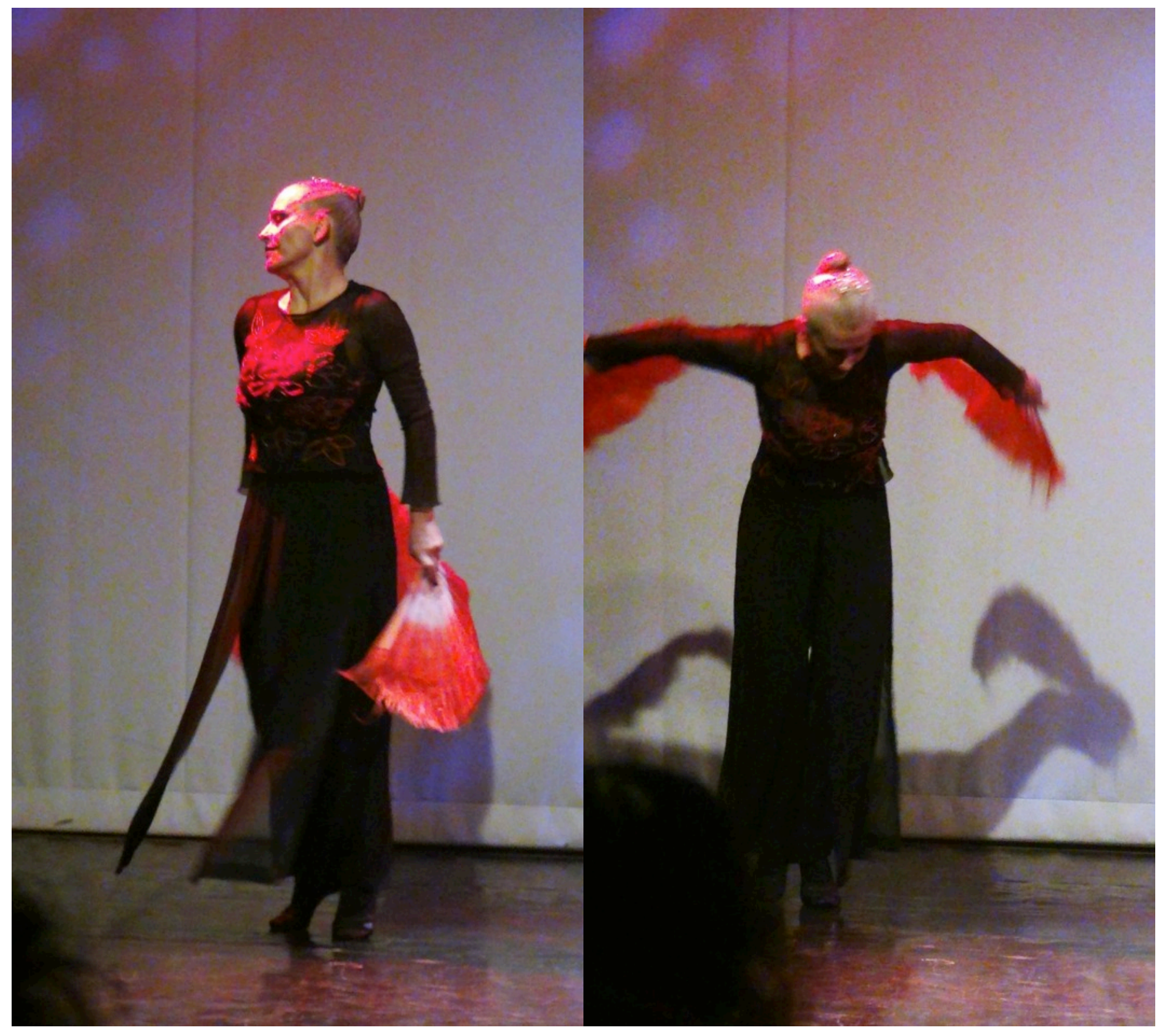


METAgraphias: letra D de Dropbox (das derivas dançantes) v.2 n.1 marçol2017

poemadançando fogo negro•Soraia Silva (soraia@unb.br)

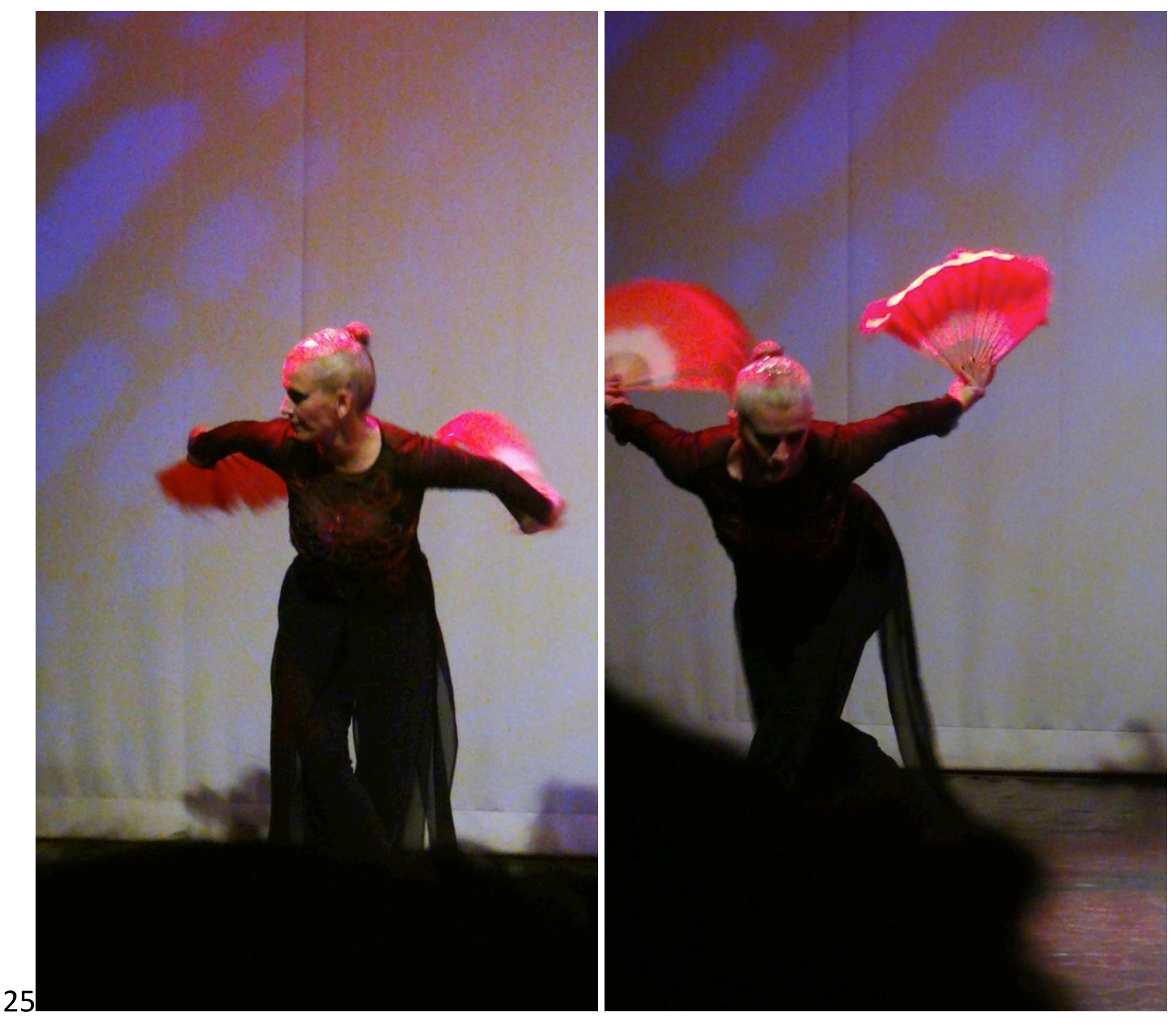




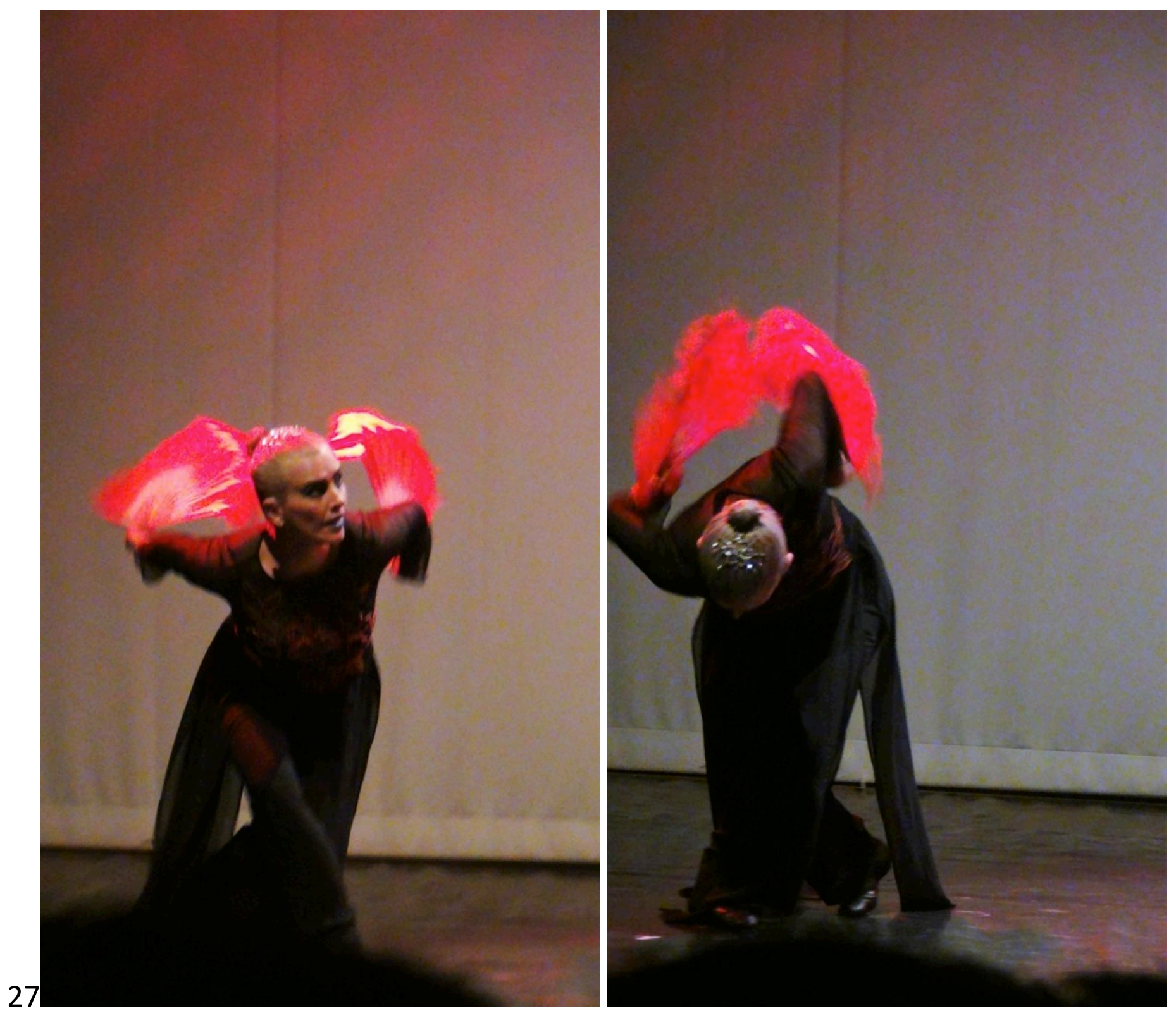




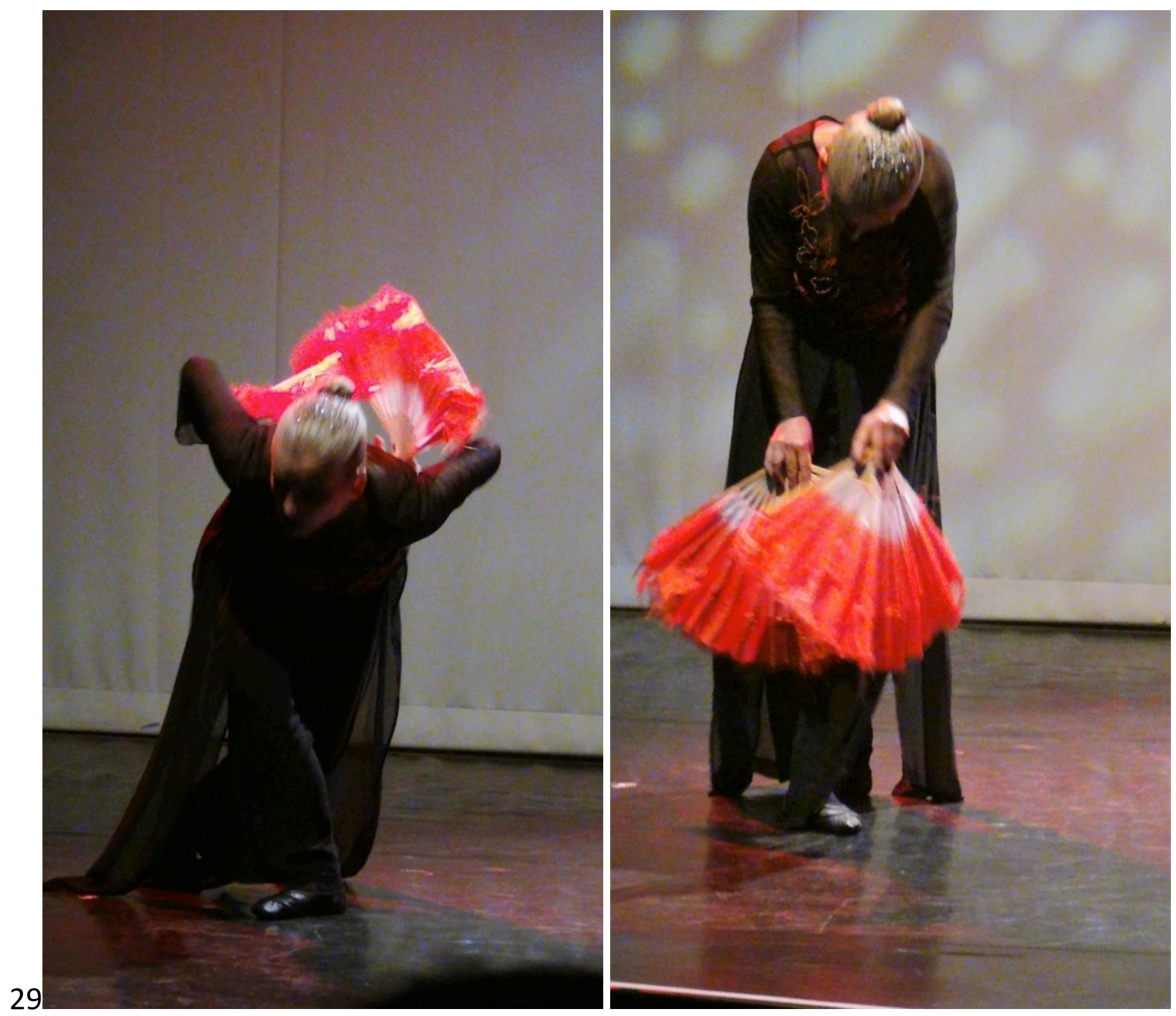


METAgraphias: letra D de Dropbox (das derivas dançantes) v.2 n.1 marçol2017 poemadançando fogo negro•Soraia Silva (soraia@unb.br)

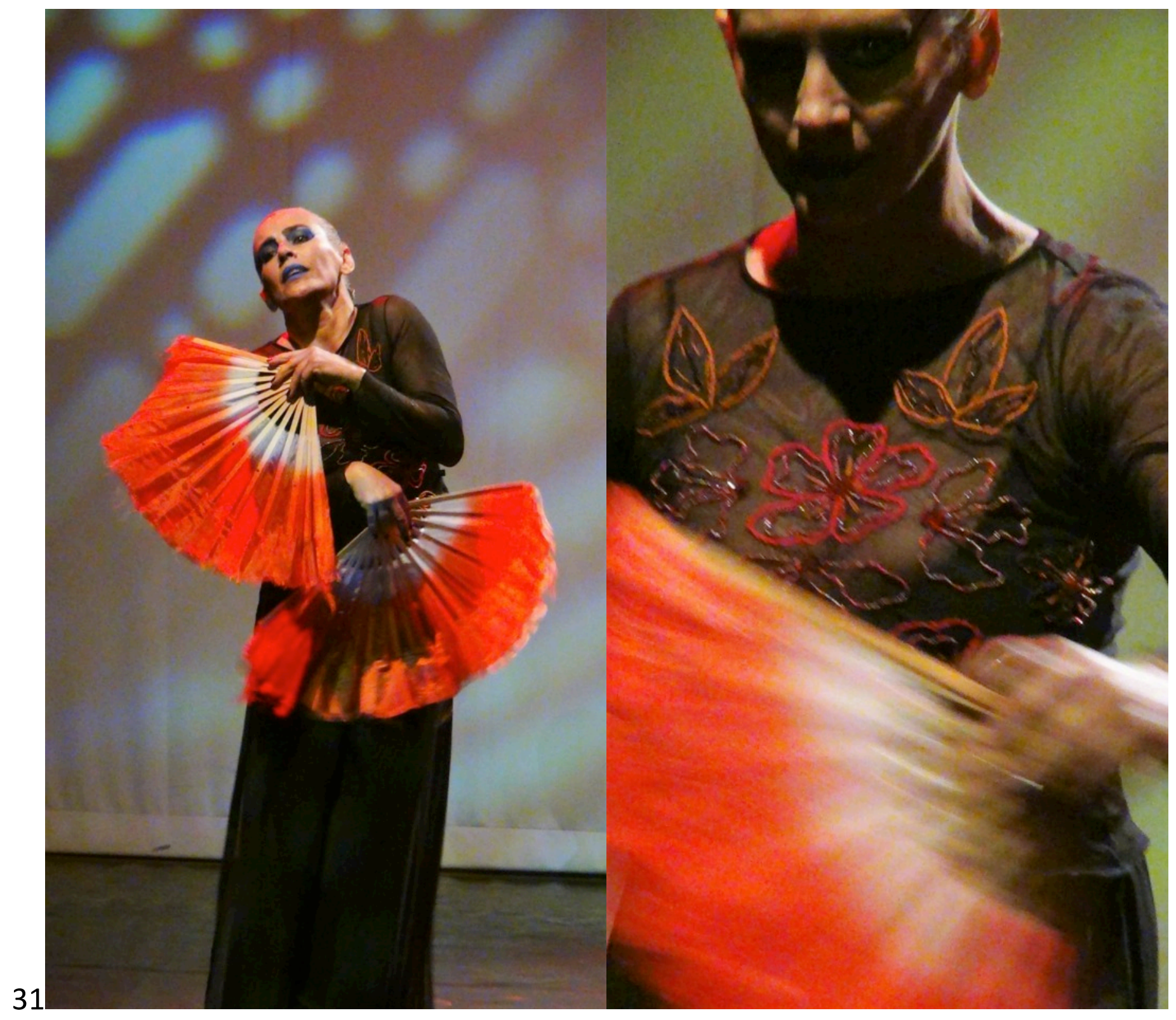




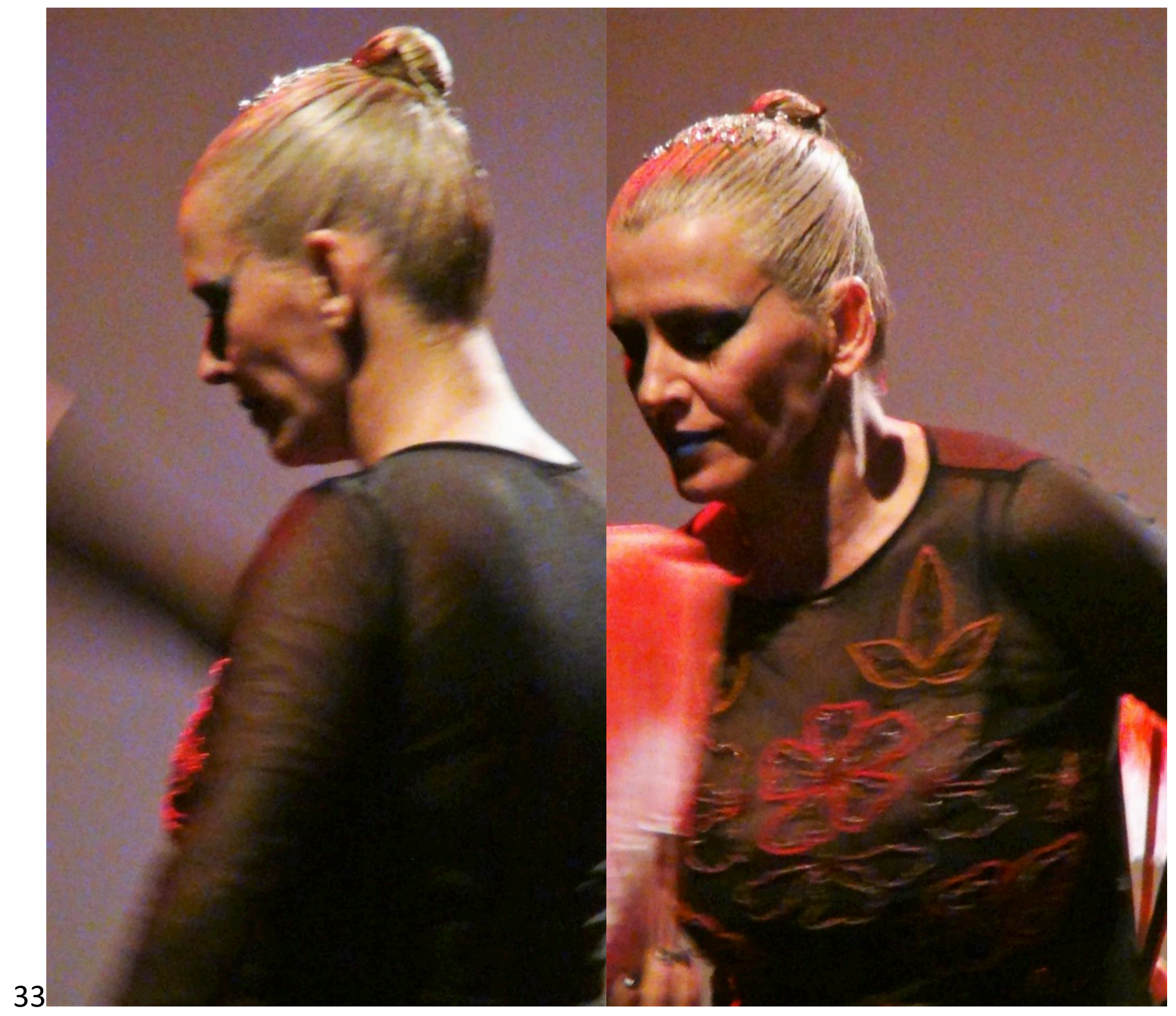




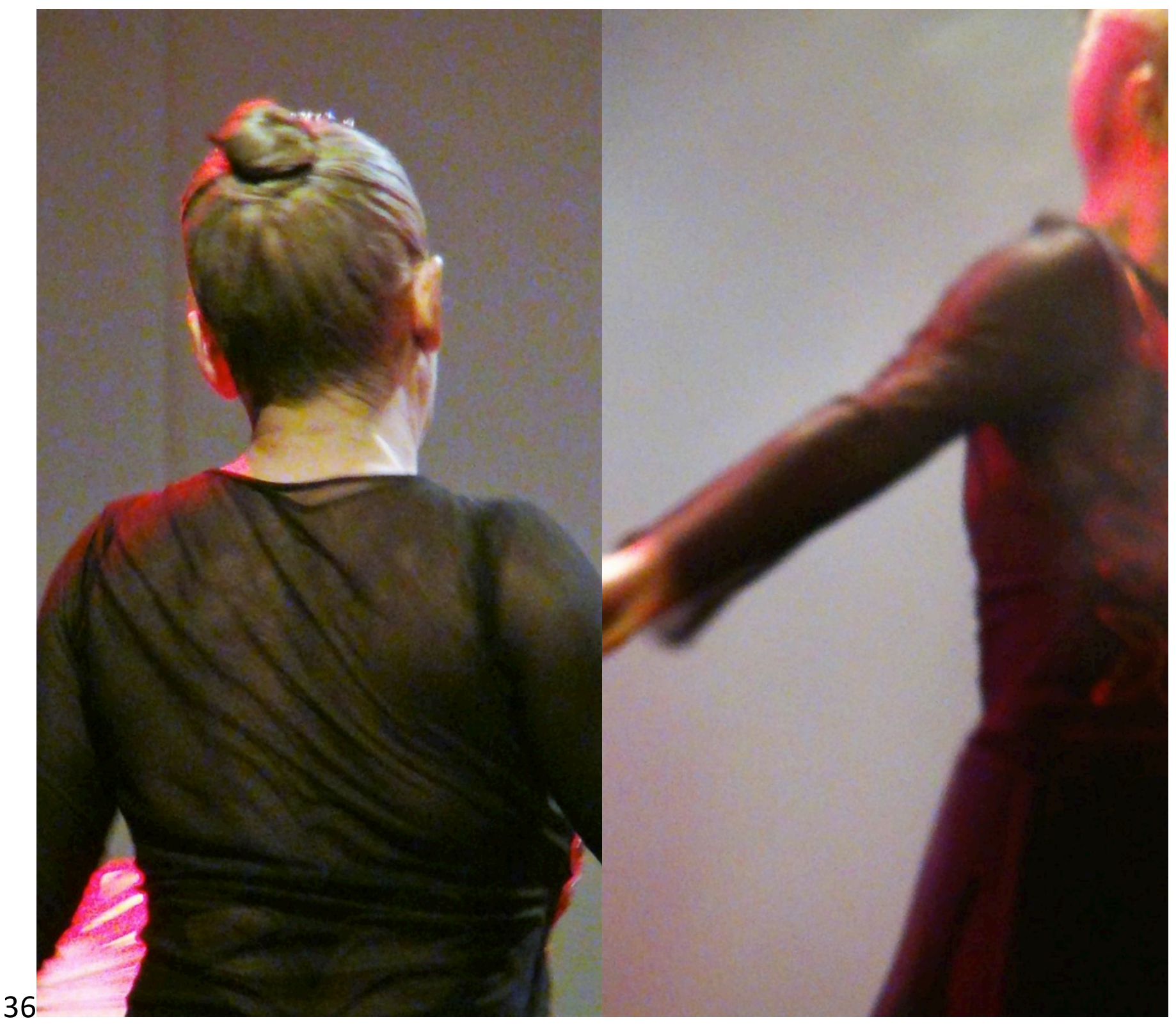




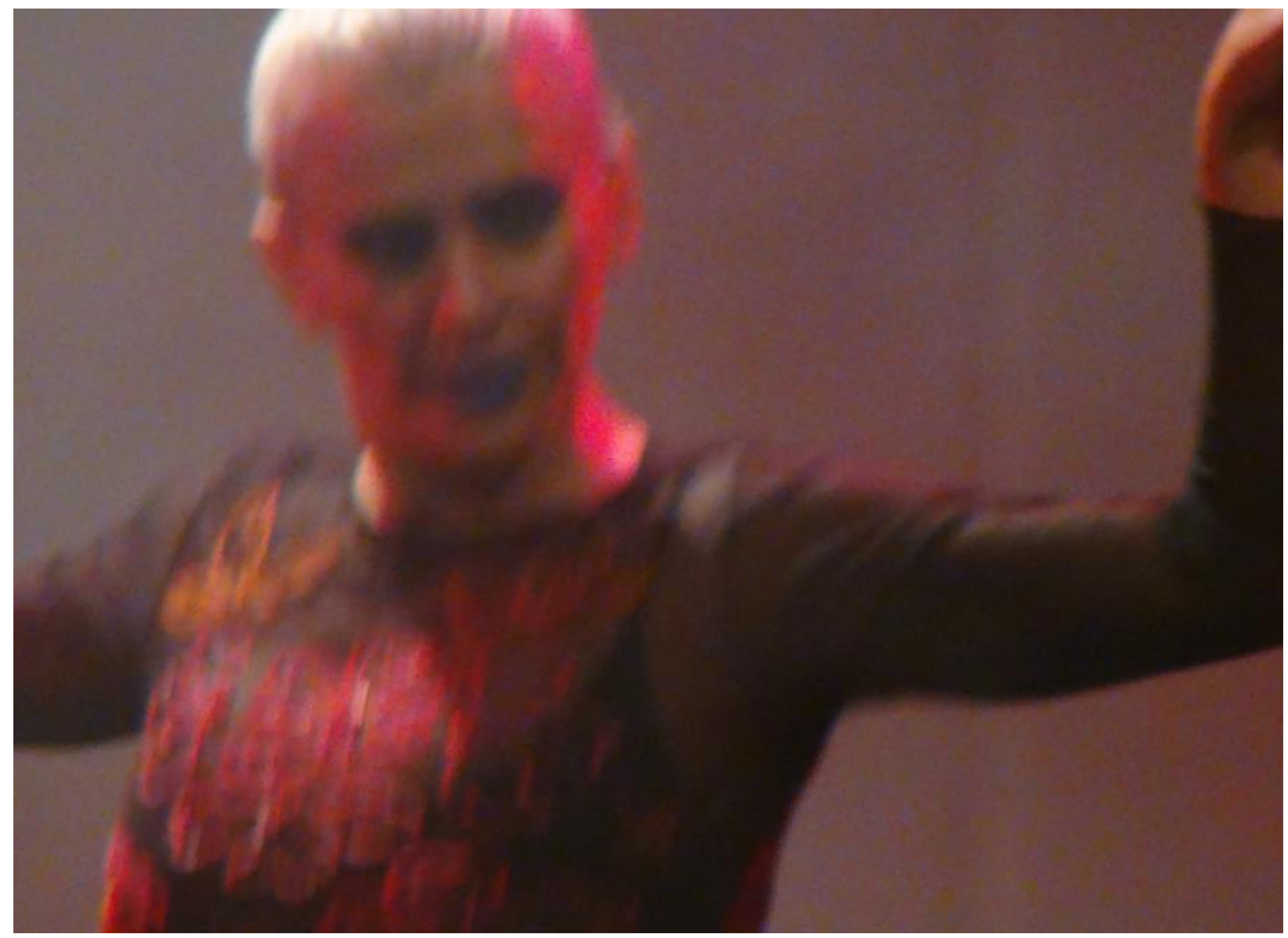


METAgraphias: letra D de Dropbox (das derivas dançantes) v.2 n.1 marçol2017 poemadançando fogo negro•Soraia Silva (soraia@unb.br)

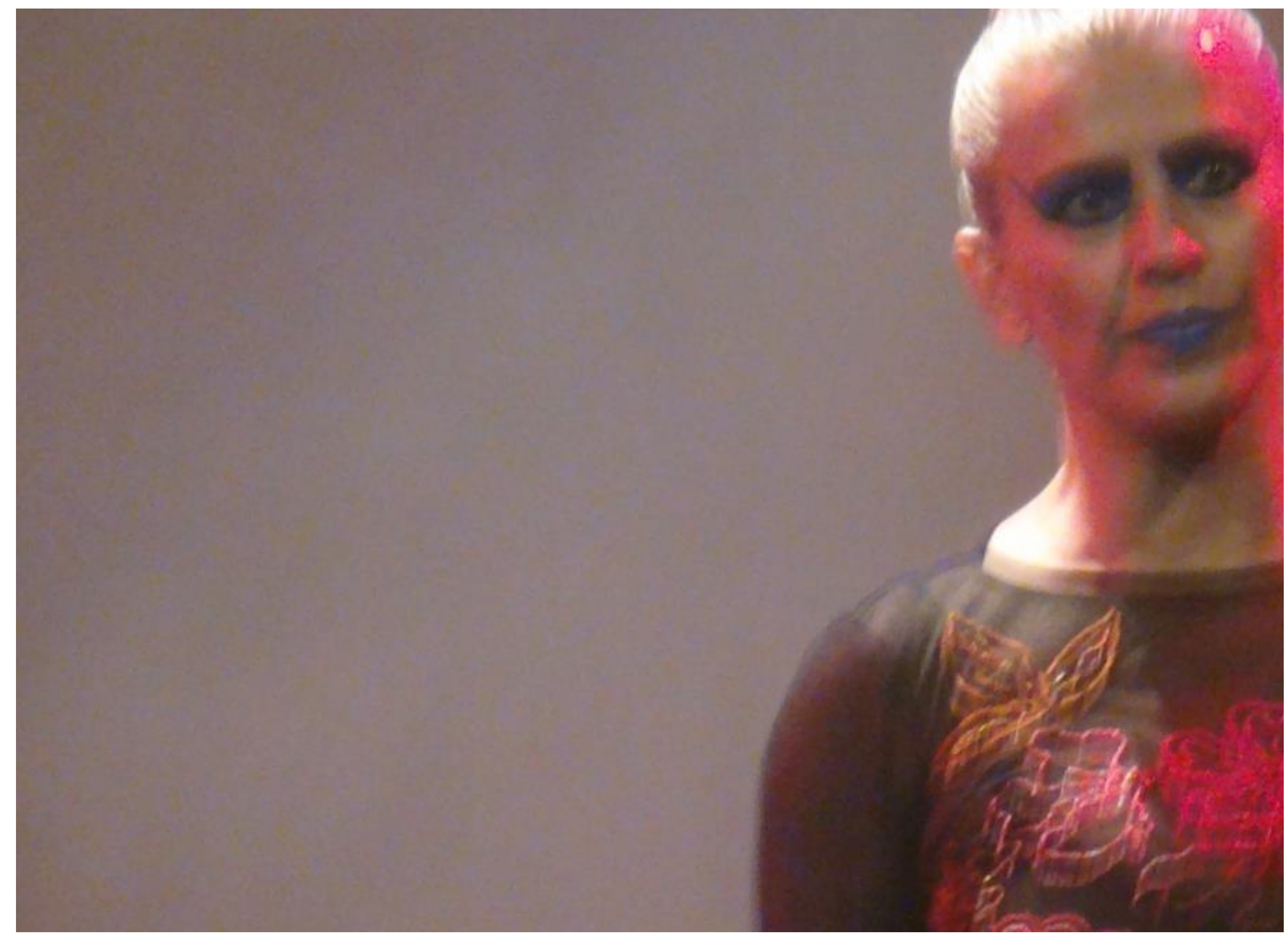


METAgraphias: letra D de Dropbox (das derivas dançantes) v.2 n.1 marçol2017 poemadançando fogo negro•Soraia Silva (soraia@unb.br)

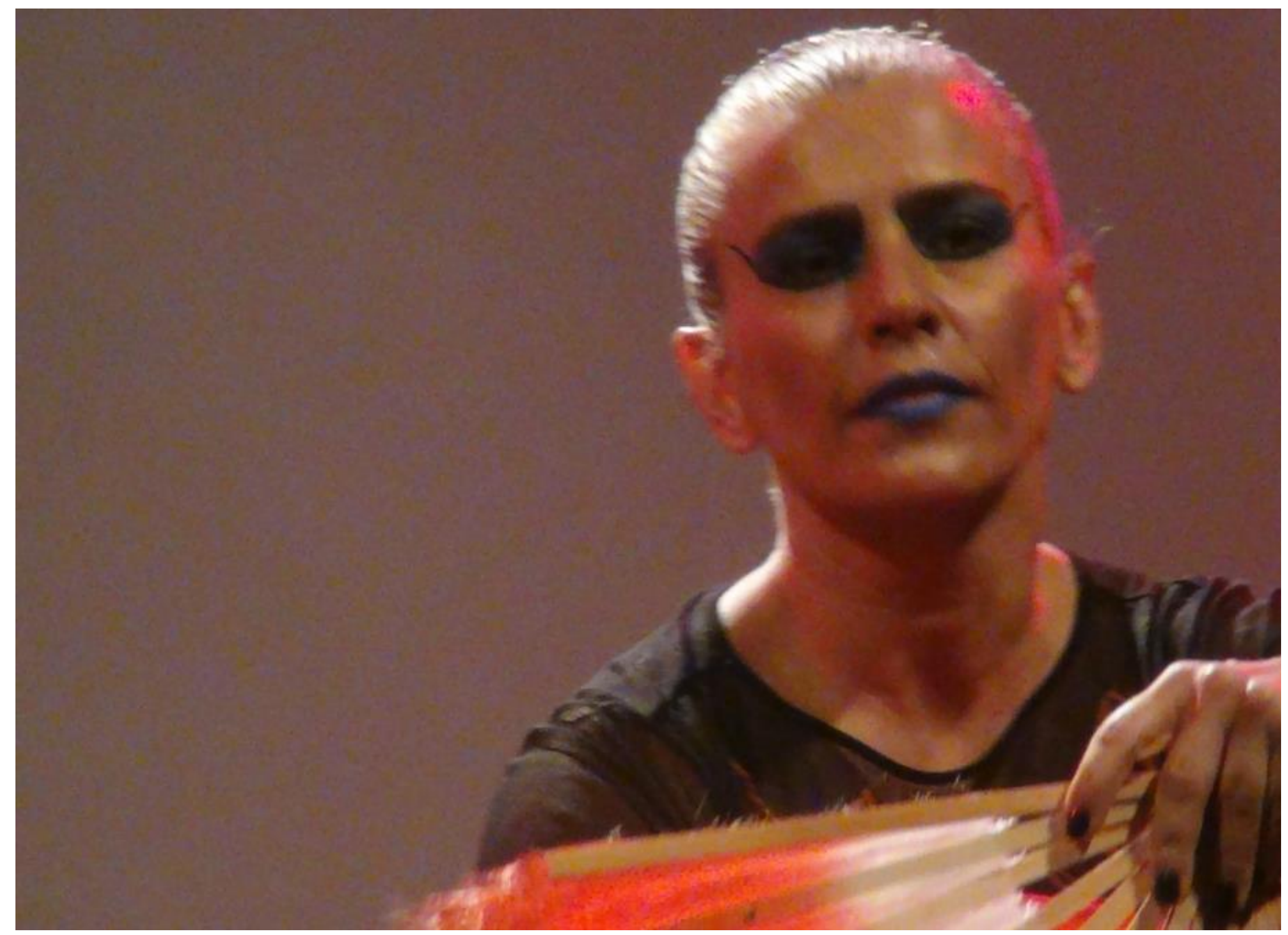


METAgraphias: letra D de Dropbox (das derivas dançantes) v.2 n.1 marçol2017 poemadançando fogo negro•Soraia Silva (soraia@unb.br)

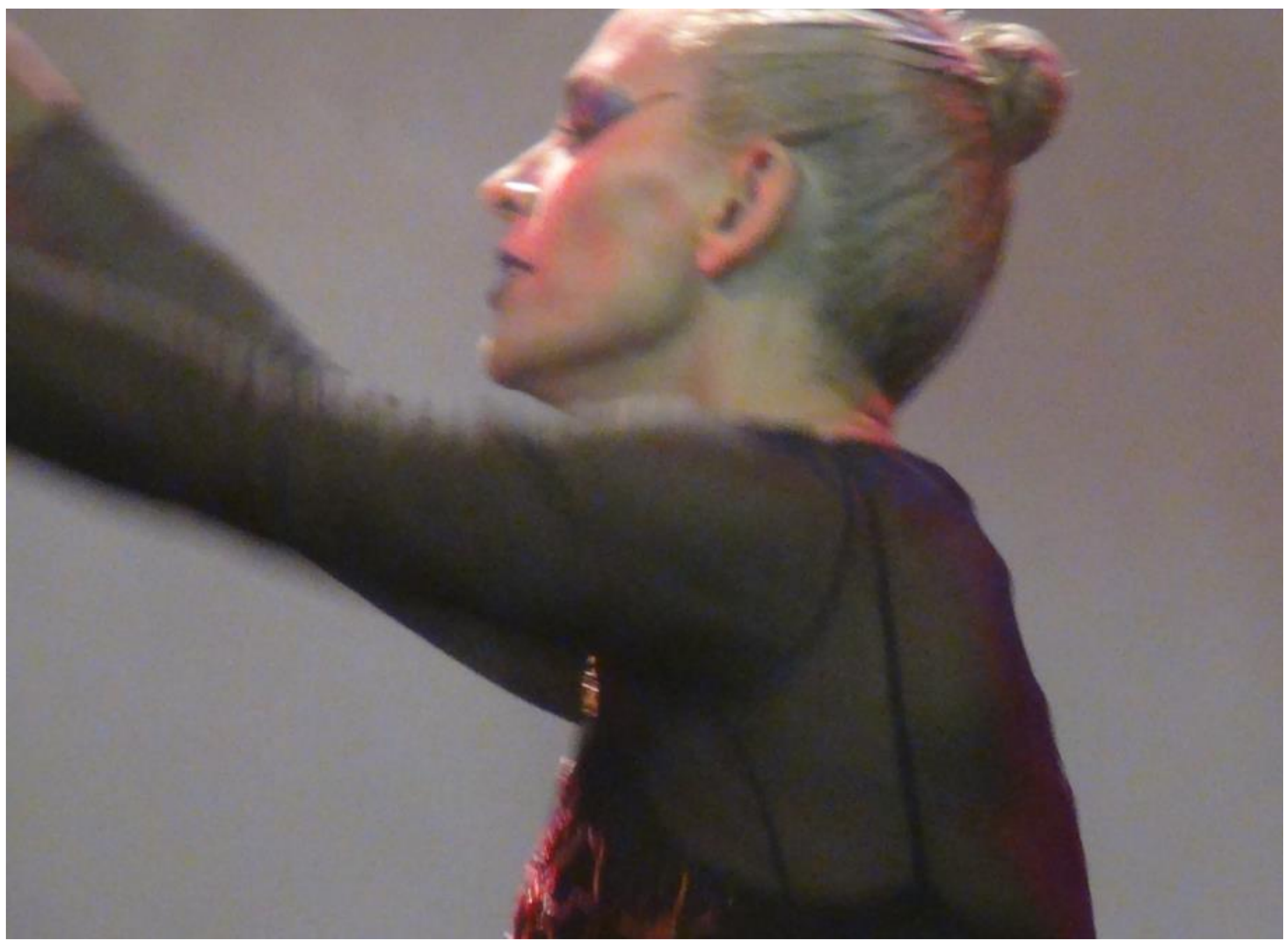




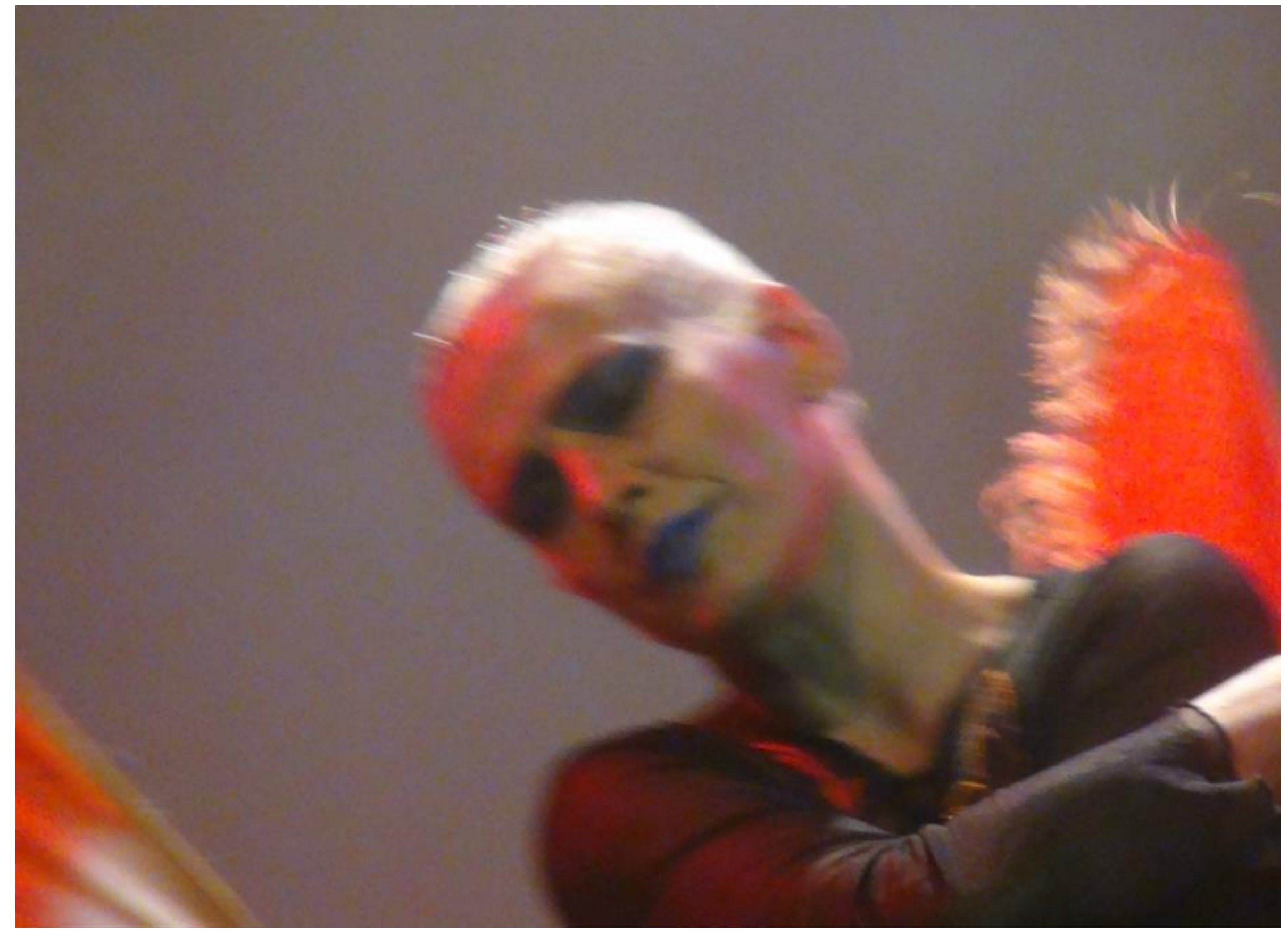




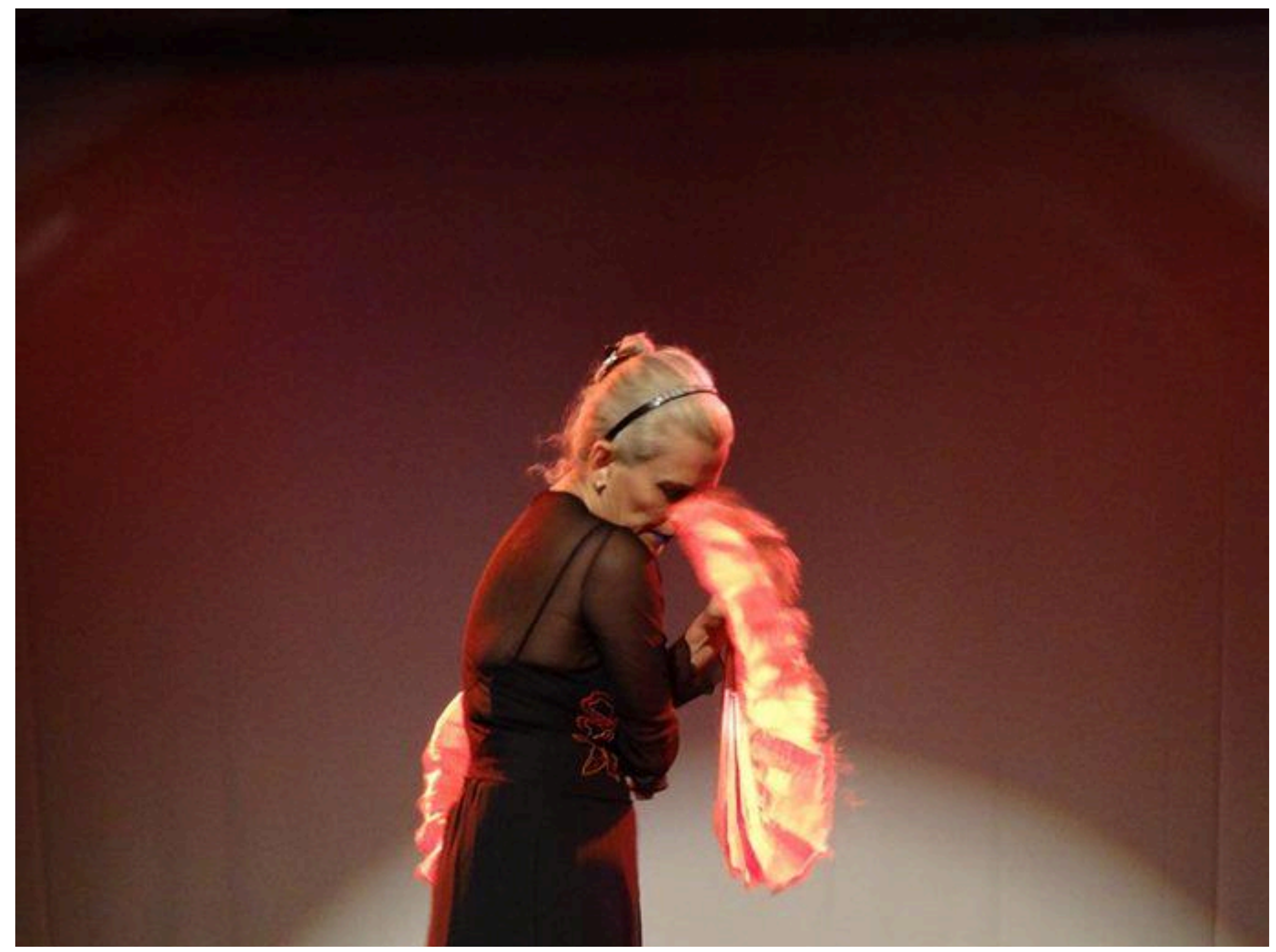




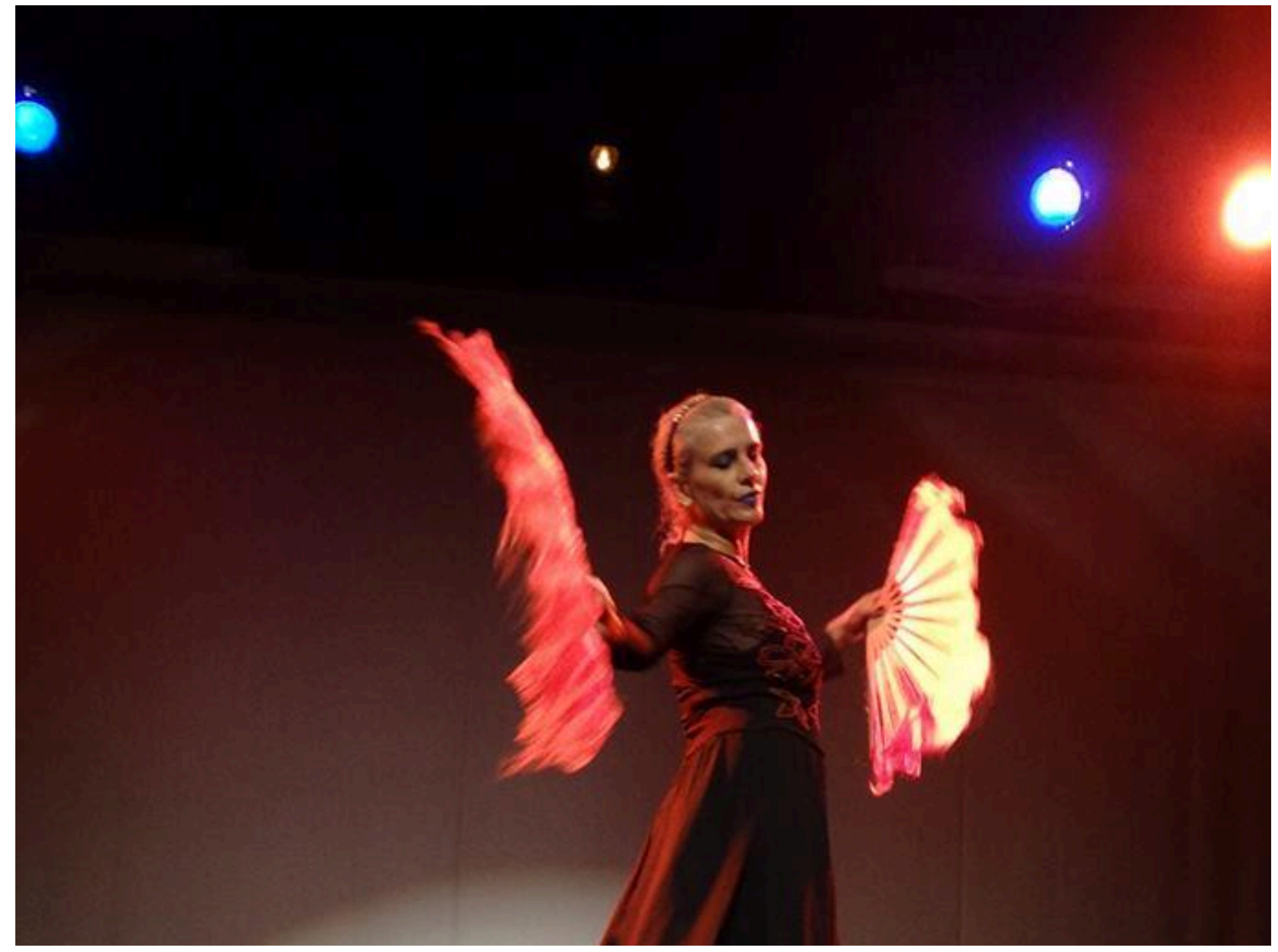




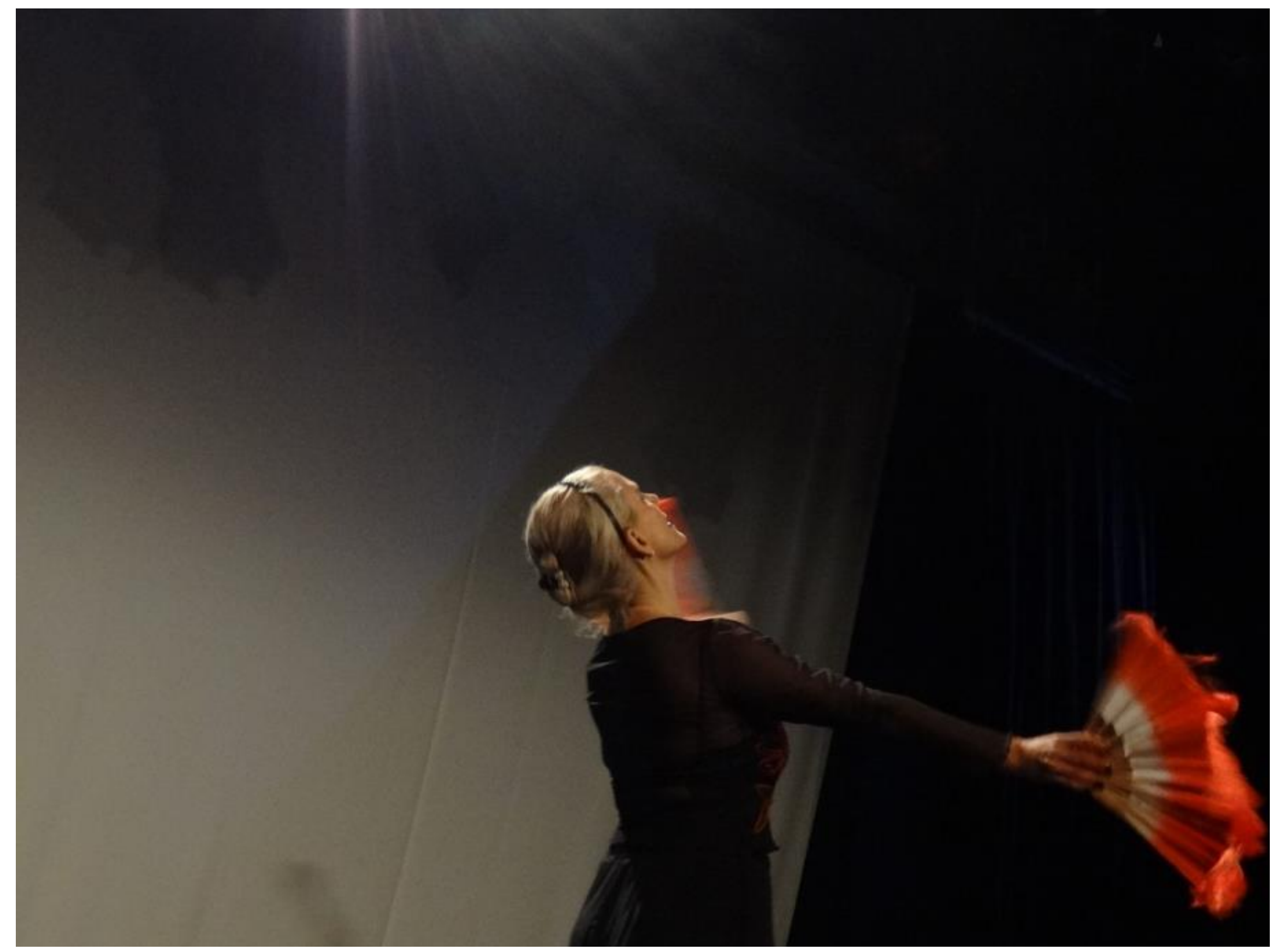




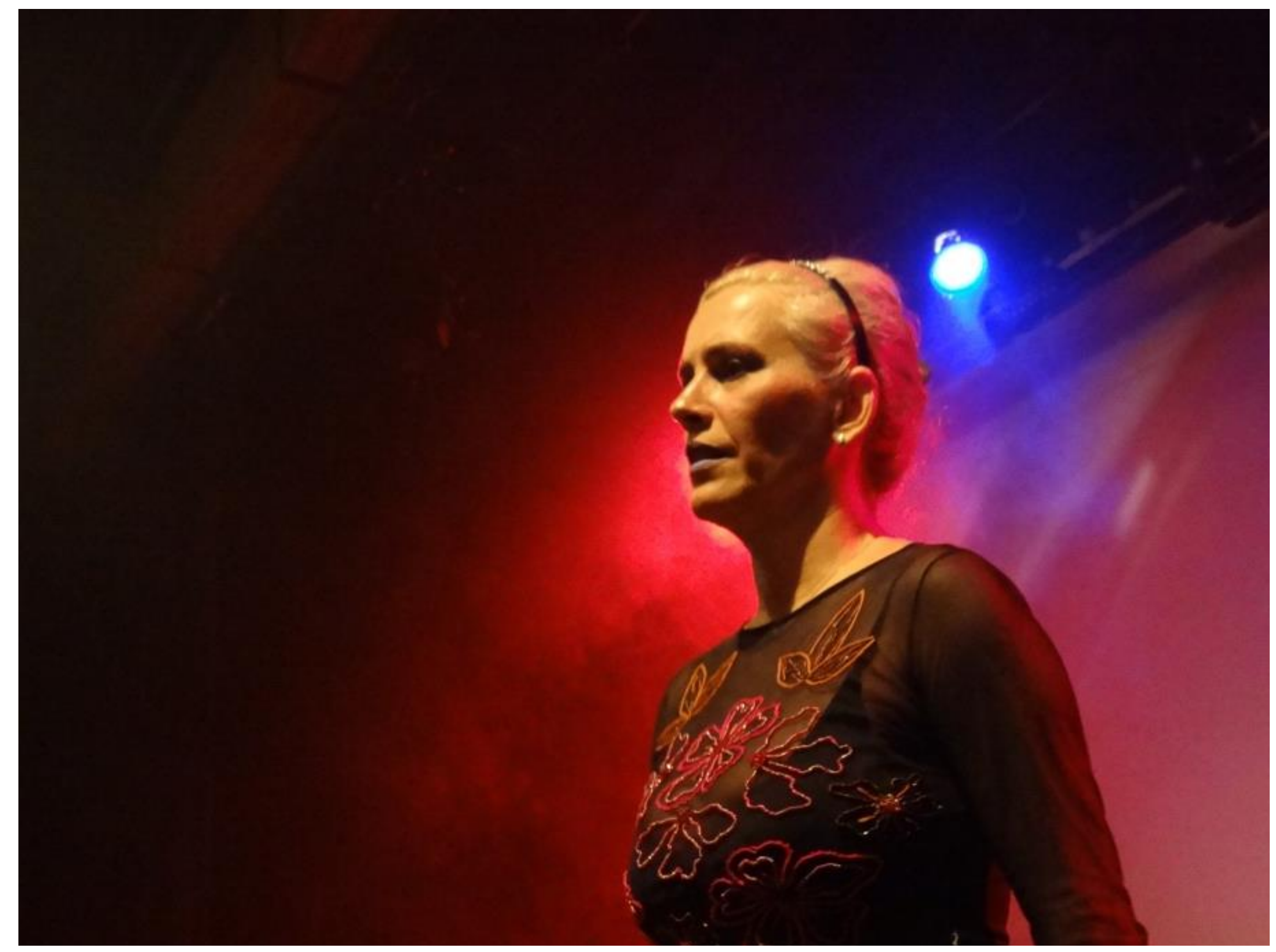




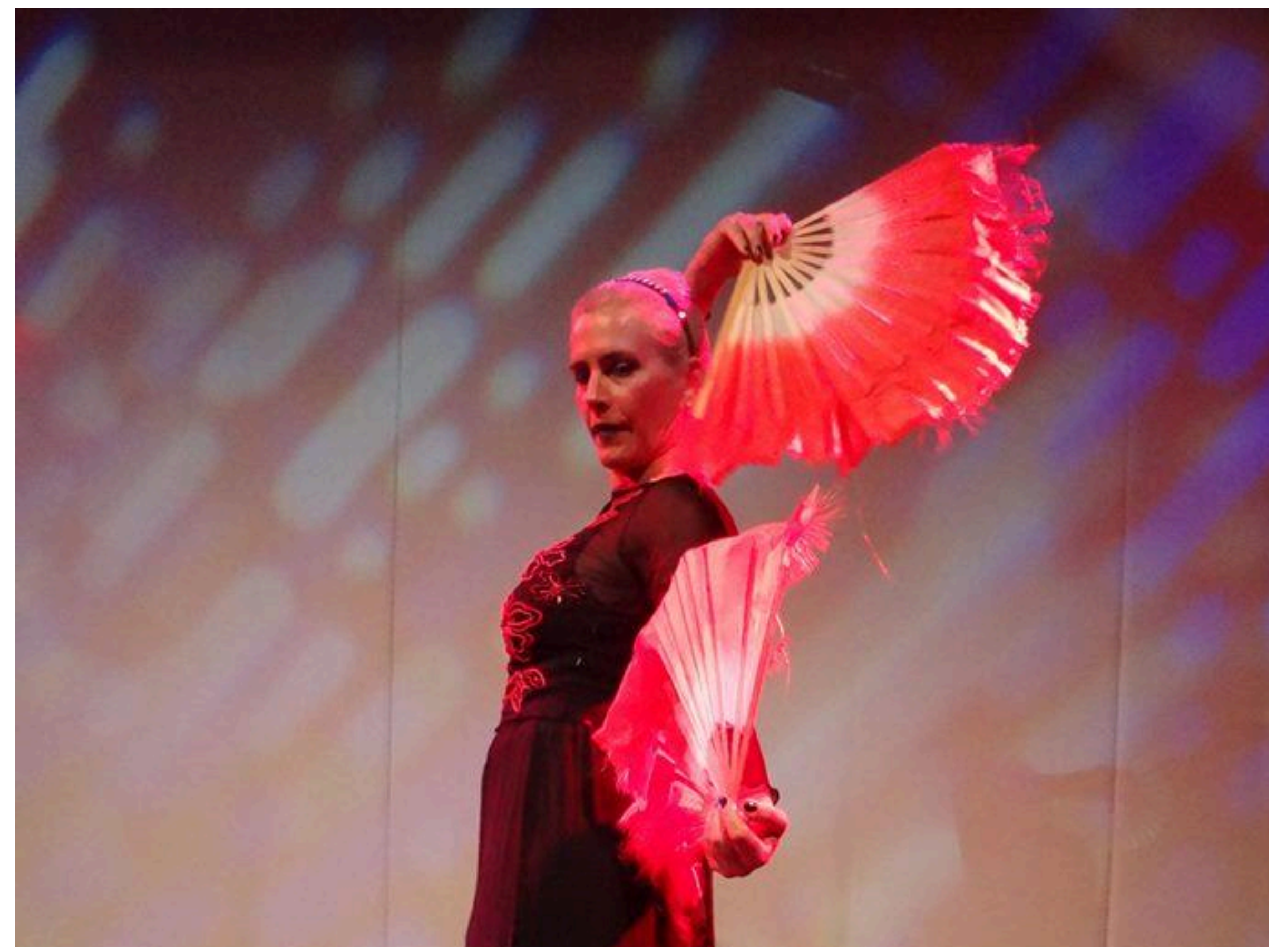




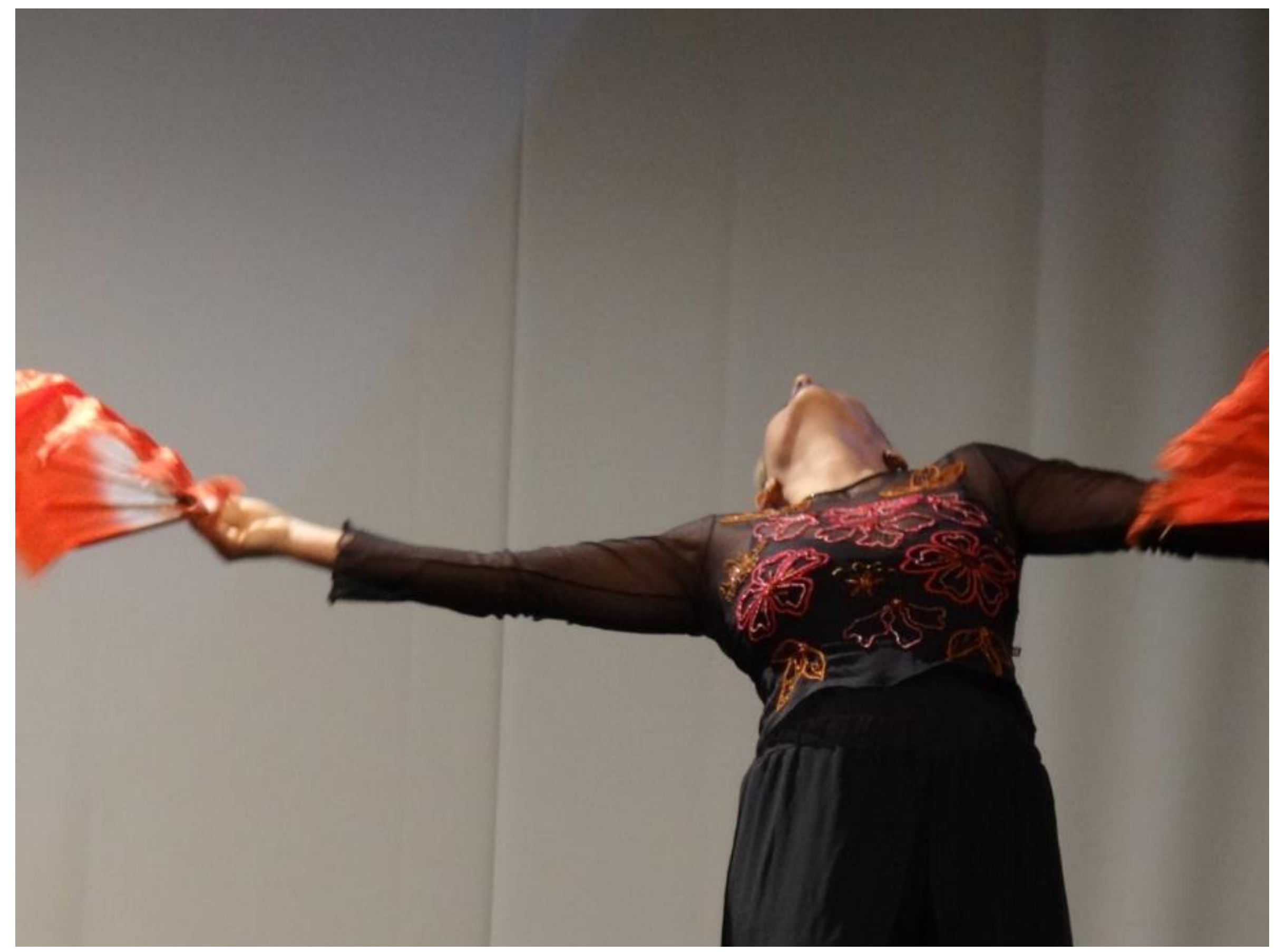




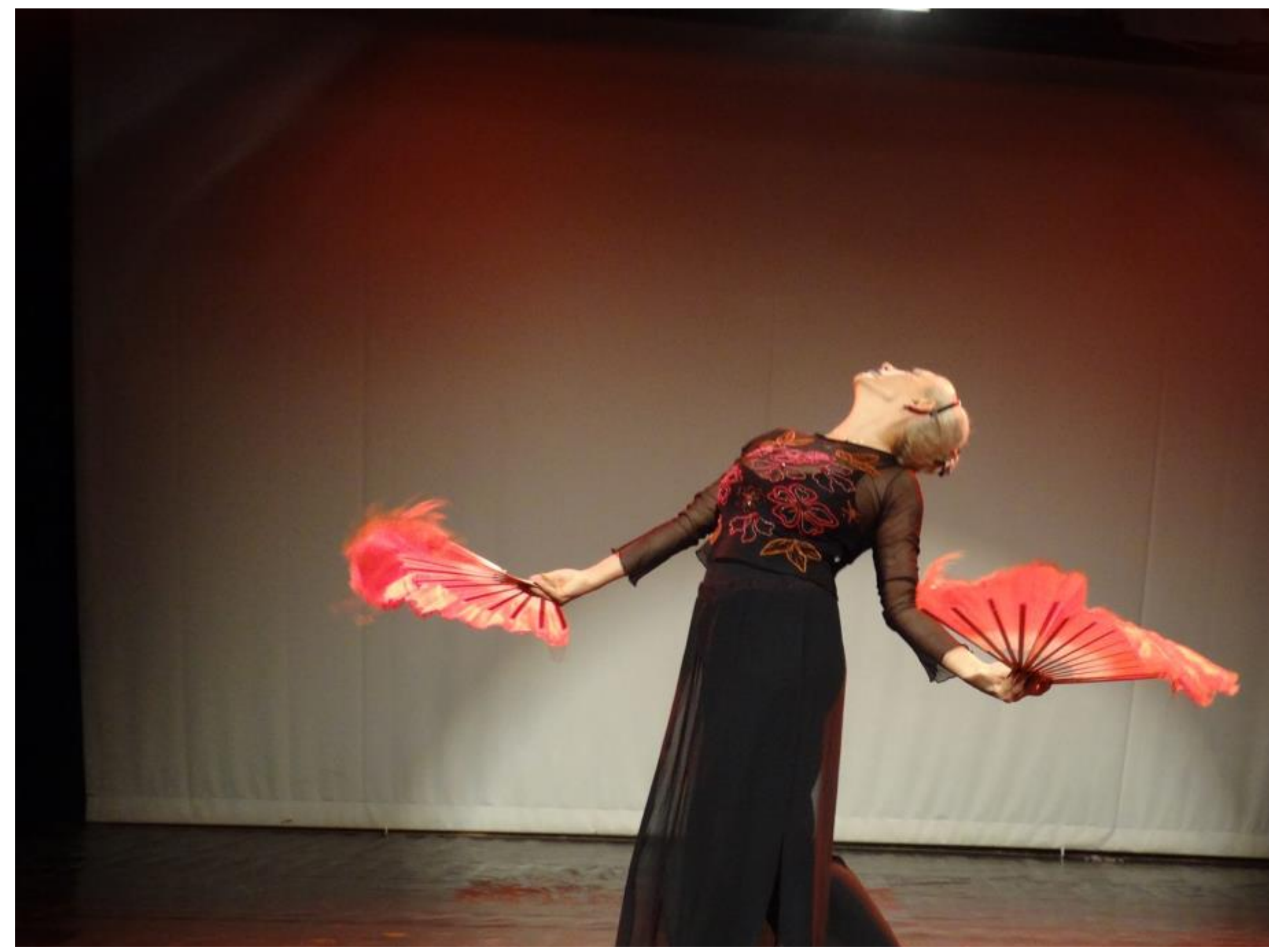




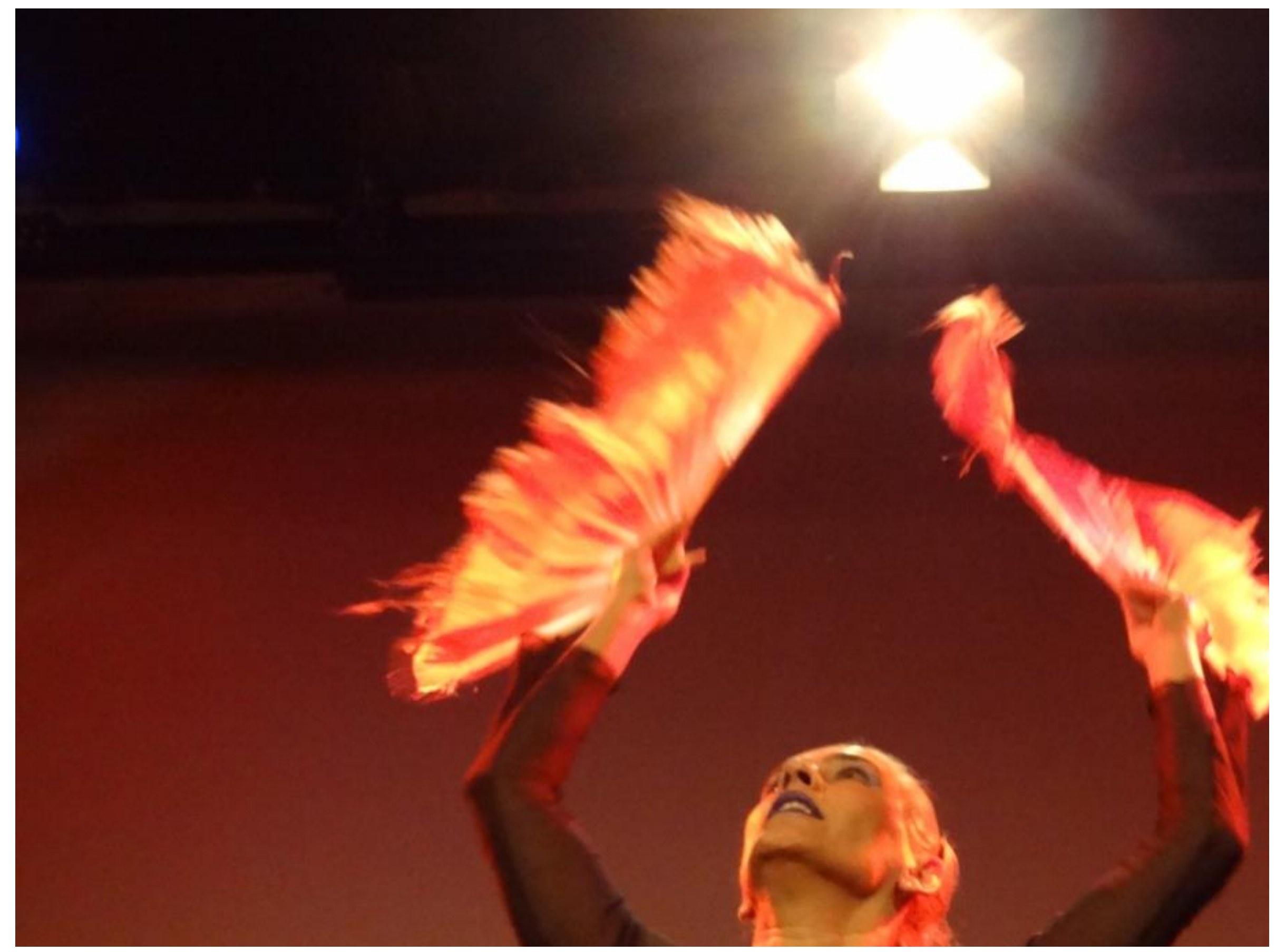




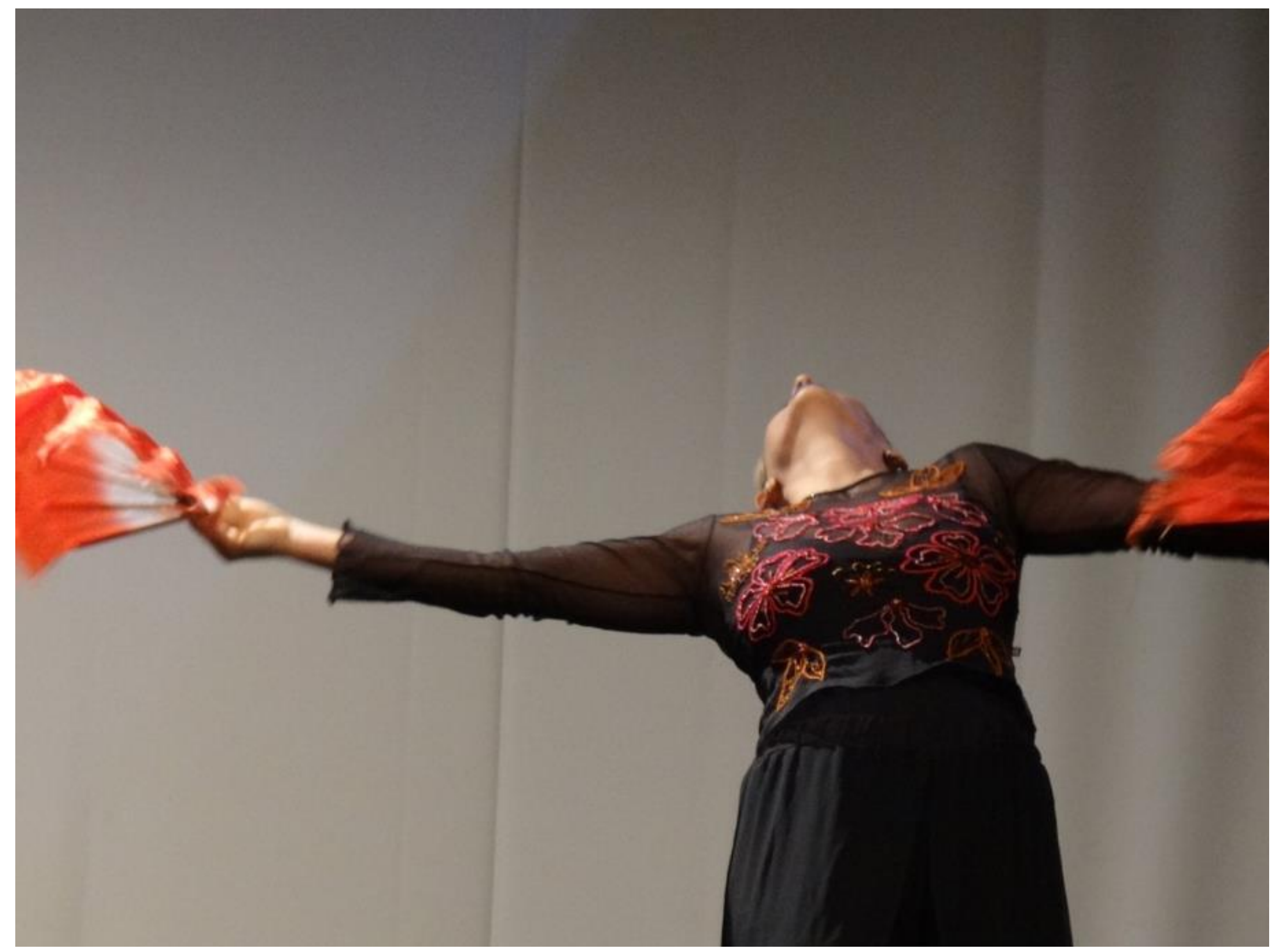

